\title{
ECM overrides DNA damage-induced cell cycle arrest and apoptosis in small-cell lung cancer cells through $\beta 1$ integrin-dependent activation of PI3-kinase
}

\author{
PS Hodkinson ${ }^{1,2}$, T Elliott ${ }^{1,2}$, WS Wong ${ }^{1}$, RC Rintoul ${ }^{1}$, \\ AC Mackinnon ${ }^{1}$, C Haslett ${ }^{1}$ and T Sethi* ${ }^{\star, 1}$ \\ ${ }^{1}$ MRC Centre for Inflammation Research, Queen's Institute of Medical \\ Research, University of Edinburgh, 51 Little France Crescent, Edinburgh EH16 \\ 4SA, UK \\ 2 These authors contributed equally to this work. \\ * Corresponding author: T Sethi, MRC Centre for Inflammation Research, \\ Queen's Institute of Medical Research, University of Edinburgh, 51 Little \\ France Crescent, Edinburgh EH16 4SA, UK. Tel: + 0044131242 6550; \\ Fax: + 0044131242 6479; E-mail: t.sethi@ed.ac.uk
}

Received 13.7.05; revised 07.11.05; accepted 24.11.05; published online 27.1.06 Edited by M Oren

\begin{abstract}
The emergence of resistance to chemotherapy remains a principle problem in the treatment of small-cell lung cancer (SCLC). We demonstrate that extracellular matrix (ECM) activates phosphatidyl inositol 3-kinase (PI3-kinase) signaling in SCLC cells and prevents etoposide-induced caspase-3 activation and subsequent apoptosis in a $\beta 1$ integrin/PI3kinase-dependent manner. Crucially we show that etoposide and radiation induce G2/M cell cycle arrest in SCLC cells prior to apoptosis and that ECM prevents this by overriding the upregulation of $\mathrm{p} 21^{\mathrm{Cip} 1 / \mathrm{WAF} 1}$ and $\mathrm{p} 27^{\mathrm{Kip} 1}$ and the downregulation of cyclins $E, A$ and $B$. These effects are abrogated by pharmacological and genetic inhibition of PI3-kinase signaling. Importantly we show that chemoprotection is not mediated by altered SCLC cell proliferation or DNA repair. Thus, ECM via $\beta 1$ integrin-mediated PI3-kinase activation overrides treatment-induced cell cycle arrest and apoptosis, allowing SCLC cells to survive with persistent DNA damage, providing a model to account for the emergence of acquired drug resistance.

Cell Death and Differentiation (2006) 13, 1776-1788. doi:10.1038/sj.cdd.4401849; published online 27 January 2006
\end{abstract}

Keywords: cancer; extracellular matrix; cell cycle; apoptosis; chemoresistance

\footnotetext{
Abbreviations: CDK, cyclin-dependent kinase; DNA-PKcs, DNA-dependent protein kinase catalytic subunit; ECM, extracellular matrix; FCS, fetal calf serum; GSK-3, glycogen synthase kinase-3; Gy, Gray; MDR, multi-drug resistance; $\mathrm{Na}_{3} \mathrm{VO}_{4}$, sodium orthovanadate; PI3-kinase, phosphatidyl inositol 3-kinase; PKB, protein kinase $\mathrm{B}$; $\mathrm{Rb}$, retinoblastoma protein; SCLC, small-cell lung cancer; Topo II, topoisomerase II; XRT, radiation; z-VAD, z-valine-alanine-aspartate
}

\section{Introduction}

Lung cancer is the most common fatal malignancy in the developed world. ${ }^{1}$ Small-cell lung cancer (SCLC), which constitutes $25 \%$ of all lung tumors, has a very poor prognosis (2-year survival less than 5\%). Etoposide-based chemotherapeutic regimens and radiotherapy are the main stay of treatment. ${ }^{2}$ Although impressive initial responses are seen, in the majority of patients, recurrent disease refractory to further treatment results in tumor relapse and ultimately death. This phenomenon, known as multi-drug resistance (MDR), is the major cause of cancer treatment failure. ${ }^{2}$ New therapeutic strategies are urgently needed, which will require an in-depth understanding of the mechanisms of MDR in SCLC.

We have previously shown that SCLC is surrounded by an extensive stroma of extracellular matrix (ECM) at both primary and metastatic sites and that high levels of expression correlate with poor patient prognosis. ${ }^{3}$ Cells interact with ECM components via heterodimeric cell surface proteins called integrins. ${ }^{4} \mathrm{ECM}$-integrin interaction stimulates signal transduction pathways that regulate a number of cellular processes important in cancer growth, including cell cycle transition and protection from apoptosis. ${ }^{4}$ We have shown that adhesion of SCLC cells via $\beta 1$ integrins to ECM components promotes cell survival and confers resistance to chemotherapeutic agents. ${ }^{3}$ This has now been demonstrated to be a general mechanism for acquired drug resistance in a number of malignancies including myeloma, breast and colon cancer. ${ }^{3,5-7}$ However, the intracellular signals activated by ECM components in cancer cells, which influence response to chemotherapy and radiotherapy, have not been fully elucidated. A clear understanding of these mechanisms is essential to the development of rational therapeutic strategies to overcome acquired MDR and enhance the effects of chemotherapy and radiotherapy.

Central to the cellular response to chemotherapy and radiation-induced DNA damage is cell cycle arrest, predominantly at the G1/S and G2/M checkpoints. ${ }^{8}$ Alterations in expression of genes that control progression through the cell cycle have been demonstrated to affect chemosensitivity. The best described in cancer cells are alterations in expression of p53 and the retinoblastoma protein (Rb). Mutated forms of p53 and/or Rb have been shown to be associated with increased resistance of tumor cells to various anticancer drugs and irradiation, mainly because of disruption of cell cycle checkpoints. ${ }^{9}$ Alterations in other cell cycle regulators such as the cyclins, cyclin-dependent kinases (CDKs) and their inhibitors, p2 $1^{\text {Cip } 1 / \text { WAF1 }}$ and p2 $7^{\text {Kip1 }}$, may also play an important role in the regulation of drug sensitivity. ${ }^{10}$

Anchorage to ECM is required for proliferation of all untransformed cells and the development of anchorage independence is an important stage in transformation. ${ }^{11}$ Regulation of the cell cycle by mitogens and cell adhesion in 
untransformed cells is restricted to the G1/S transition. ${ }^{12,13}$ Progression through the G1 phase is mediated by CDK 2, 4 and 6 , whose activities are controlled by their associated cyclins and CDK inhibitors, p21 ${ }^{\text {Cip1/WAF1 }}$ and p27 Kip1 ${ }^{14}$ Accumulation of cyclin $\mathrm{D}$, which associates with and activates CDK 4 and 6 , initiates progression through $\mathrm{G1} .^{15}$ The cyclin D-CDK 4 and 6 complex also prevents transcriptional repression of cyclin $E$ and the de-repression of cyclin $A$, promoting the onset of $S$ phase. ${ }^{16}$ Cells in suspension have higher levels of CDK 2 inhibitors than do attached cells, leading to impaired cyclin E-CDK 2 activity with resultant cell cycle arrest in late $\mathrm{G} 1 .{ }^{14,17}$ These results suggest that the regulation of cyclin E-CDK 2 activity is an important mechanism by which anchorage to ECM controls progression through the G1/S transition in untransformed cells. Regulation of cyclin E-CDK 2 activity may also represent how ECM protects cancer cells from chemotherapy-induced cell cycle arrest and subsequent apoptosis.

The phosphatidyl inositol 3-kinase (PI3-kinase) signaling pathway has been demonstrated to be an essential survival signal in SCLC cells, and is a key regulator of cell cycle progression. ${ }^{18,19}$ Integrin activation by ECM couples integrin cytoplasmic tails to focal adhesion kinase and activates PI3kinase, which phosphorylates inositol lipids, leading to activation of protein kinase $B(P K B)$ and phosphorylation of glycogen synthase kinase $3 \beta$ (GSK3 $\beta$ ). ${ }^{19,20}$ PKB phosphorylates and inactivates proapoptotic factors such as caspase 9 and Bad, preventing apoptosis. ${ }^{19}$ Phosphorylation of GSK3 $\beta$ stabilizes cyclin $D 1$, promoting progression through $\mathrm{G} 1$ phase of the cell cycle, and prevents apoptosis by altering gene expression through NF- $\kappa \mathrm{B}$ and $\mathrm{AP}-1 .{ }^{21-23}$ Therefore, prevention of cell cycle arrest and subsequent apoptosis through integrin activation of PI3-kinase may represent an important mechanism by which ECM proteins protect SCLC cells from chemotherapy and radiation.

In this paper, we demonstrate that ECM proteins can override etoposide-induced G2/M cell cycle arrest and apoptosis in SCLC cells through $\beta 1$ integrin activation of tyrosine kinase/PI3-kinase signaling. Furthermore, we show that ECM-mediated protection from etoposide occurs despite topoisomerase II (Topo II) inhibition and DNA double-strand break formation allowing the survival of DNA damaged cells. Thus, integrin activation by ECM proteins may provide a central mechanism for the emergence of MDR in cancer.

\section{Results}

\section{ECM proteins protect SCLC cells from chemotherapy- and radiation-induced apoptosis via $\beta 1$ integrin activation}

We have previously shown that SCLC ceslls are surrounded by the ECM proteins laminin and fibronectin in vivo, and that the degree of expression of ECM adversely affects patient prognosis. ${ }^{3}$ To elucidate the mechanism by which ECM promotes SCLC cell survival, we investigated the effect of specific ECM proteins in vitro on apoptosis induced in SCLC cells by etoposide and ionizing radiation. H345 SCLC cells were adhered to poly-L-lysine, fibronectin or laminin and treated with etoposide $(25 \mu \mathrm{g} / \mathrm{ml})$. The percentage of apoptotic cells was assessed by acridine orange/ethidium bromide staining at time points over a period of $72 \mathrm{~h}$. Apoptosis induced by etoposide was first evident at $24 \mathrm{~h}$ in H345 SCLC cells adhered to poly-L-lysine, reaching a maximum at 48-72 h (Figure 1a). No significant difference was observed whether cells were plated onto tissue culture plastic or adhered to poly-L-lysine (data not shown). However, adhesion to both laminin and fibronectin significantly protected H345 SCLC cells from apoptosis at all time points (Figure 1a). This effect was not due to a physical interaction between etoposide and ECM, as medium that had been treated with etoposide and incubated with laminin-coated plastic for $72 \mathrm{~h}$ was still able to induce apoptosis when added to SCLC cells adhered to poly-L-lysine (Figure 1b). Furthermore, adhesion of $\mathrm{H} 345$ SCLC cells to ECM proteins protected SCLC cells against the proapoptotic effect of ionizing radiation (Figure $1 \mathrm{c}$ and $\mathrm{d}$ ), further confirming that ECM protection is not caused by a physical effect on chemotherapeutic agents. Similar results were seen with $\mathrm{H} 69$ and H510 cells (data not shown). These results were confirmed using two other methods for assessing apoptosis: a cell death detection ELISA kit which is based on the quantitative detection of histone-associated DNA fragments in mono- and oligonucleosomes (Figure 1e) and annexin $\mathrm{V}$ expression (data not shown). To determine whether this survival benefit was due to an increase in the growth rate of cells on ECM, we compared the growth of H345 SCLC cells adhered to laminin or poly-L-lysine (Figure 1f). ECM proteins stimulated a small increase in cellular growth over 9 days. However, there was no significant difference in cell number between H345 cells grown on ECM or on poly-L-lysine at the early time points corresponding to when apoptosis was being assessed. These results indicate that the ECM-mediated protection of SCLC cells from chemotherapy is due to an antiapoptotic effect and not increased growth.

We have previously characterized integrin expression on SCLC cells and the $\beta 1$ integrin subunit is highly expressed. ${ }^{3}$ To investigate whether the antiapoptotic effect of ECM proteins was mediated by the activation of $\beta 1$ integrins on SCLC cells, we used specific $\beta 1$ integrin function blocking and stimulating antibodies to manipulate ECM chemoprotection. H345 SCLC cells were adhered to poly-L-lysine or laminin, treated with etoposide $(25 \mu \mathrm{g} / \mathrm{ml})$, and apoptosis was assessed at $48 \mathrm{~h}$ by acridine orange/ethidium bromide staining (Figure 1g) and annexin V (Figure 1h). The basal level of apoptosis in H345 SCLC cells on poly-L-lysine was $8 \pm 2 \%$, and this was increased to $55 \pm 4 \%$ in the presence of etoposide ( $n=3$ independent experiments in quadruplicate \pm S.E.M.). Adhesion of H345 SCLC cells to the ECM proteins laminin or fibronectin significantly reduced apoptosis caused by etoposide at $48 \mathrm{~h}$ from $55 \pm 4$ to $7 \pm 1.7$ and $8 \pm 1.4 \%$, respectively $(n=3$ independent experiments in quadruplicate \pm S.E.M.). ECM-mediated protection from etoposide-induced apoptosis was completely abolished by preincubation of $\mathrm{H} 345$ SCLC cells with the $\beta 1$ integrin function-blocking antibody (4B4 $10 \mu \mathrm{g} / \mathrm{ml})$. Furthermore, the $\beta 1$-stimulating antibody TS2 $/ 16(10 \mu \mathrm{g} / \mathrm{ml})$ and the broadspectrum phosphatase inhibitor sodium orthovanadate $\left(\mathrm{Na}_{3} \mathrm{VO}_{4}\right)$ both reproduced the effects of ECM proteins. Taken together, these results indicate that ECM proteins 

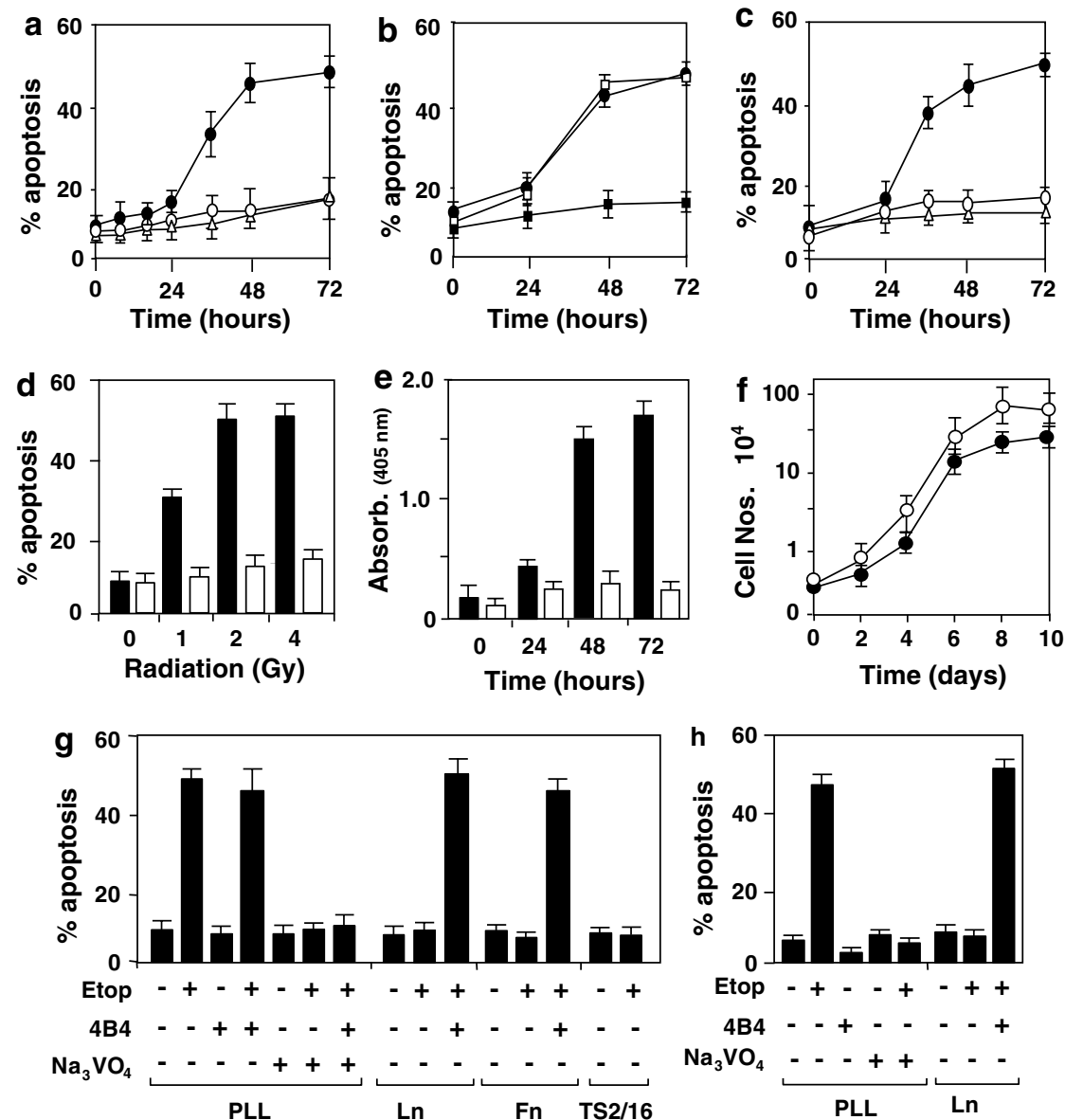

Figure 1 ECM-mediated protection from etoposide- and radiation-induced apoptosis in SCLC cells is $\beta 1$ integrin-dependent. (a) H345 SCLC cells were seeded into 96-well plates precoated with poly-L-lysine $(10 \mu \mathrm{g} / \mathrm{ml})(\bullet)$, laminin $(10 \mu \mathrm{g} / \mathrm{ml})(\bigcirc)$ or fibronectin $(20 \mu \mathrm{g} / \mathrm{ml})(\triangle)$, and treated with etoposide $(25 \mu \mathrm{g} / \mathrm{ml})$. The percentage of apoptotic cells was determined at the times indicated by staining cells with acridine orange/ethidium bromide and subsequent fluorescent microscopy (mean of $n=3$ independent experiments in quadruplicate \pm S.E.M.). (b) Quiesced H345 SCLC cells were seeded into 96-well plates precoated with poly-L-lysine (10 $\mu \mathrm{g} / \mathrm{ml})$ and treated with etoposide $(25 \mu \mathrm{g} / \mathrm{ml})(-)$ or seeded on poly-L-lysine in a medium that had been conditioned by incubation for $72 \mathrm{~h}$ in laminin-coated $(10 \mu \mathrm{g} / \mathrm{ml})$ six-well plates with $(\square)$ or without $(\boldsymbol{\square})$ etoposide $(25 \mu \mathrm{g} / \mathrm{ml})$. The percentage of apoptotic cells was determined as above (mean of $n=3$ independent experiments in quadruplicate \pm S.E.M.). (c) Quiesced H345 SCLC cells were seeded into 96-well plates precoated with poly-L-lysine $(10 \mu \mathrm{g} / \mathrm{ml})(\mathbf{O})$, laminin $(10 \mu \mathrm{g} / \mathrm{ml})(\bigcirc)$ or fibronectin $(20 \mu \mathrm{g} / \mathrm{ml})(\triangle)$, and treated with ionizing radiation (2Gy). The percentage of apoptotic cells was determined as above (mean of $n=3$ independent experiments in quadruplicate + S.E.M.). (d) Quiesced H345 cells were adhered to poly-L-lysine $(10 \mu \mathrm{g} / \mathrm{ml})$ (black bar) or laminin $(10 \mu \mathrm{g} / \mathrm{ml})($ white bar), treated with ionizing radiation ( $0-4 \mathrm{~Gy}$ ) as indicated, and the percentage of apoptotic cells was determined at $48 \mathrm{~h}$ (mean of $n=3$ independent experiments in quadruplicate + S.E.M.). (e) H345 cells were adhered to poly-L-lysine (black bar) or laminin (white bar) and treated with etoposide ( $25 \mu \mathrm{g} / \mathrm{ml})$. Apoptosis was assessed at the time indicated using a cell death ELISA kit. The graph represents the mean absorbance at $405 \mathrm{~nm}$ from $n=3$ experiments \pm S.E.M. Increase in absorbance indicates increased apoptosis. (f) H345 SCLC cells were plated into 24-well plates coated with poly-L-lysine $(\mathbf{O})$ or laminin $(O)$ and cell numbers were counted at times indicated (mean $n=4$ independent experiments \pm S.E.M.). (g) Quiesced H345 cells were incubated with $(+)$ or without $(-)$ the function blocking anti- $\beta 1$ integrin antibody 4B4 $(10 \mu \mathrm{g} / \mathrm{ml})$ for $30 \mathrm{~min}$ at $37^{\circ} \mathrm{C}$ as indicated, and then seeded into 96-well plates precoated with poly-L-lysine (PLL) $(10 \mu \mathrm{g} / \mathrm{ml})$, laminin (Ln) $(10 \mu \mathrm{g} / \mathrm{ml})$, fibronectin ( $\mathrm{Fn})(20 \mu \mathrm{g} / \mathrm{ml})$ or the integrin-activating antibody TS2/16 $(10 \mu \mathrm{g} / \mathrm{ml})$. Cells were treated with $(+)$ or without $(-)$ etoposide $(\mathrm{Etop})\left(25 \mu \mathrm{g} / \mathrm{ml}^{2}\right)$ or $\mathrm{Na}_{3} \mathrm{VO}{ }_{4}$ $(200 \mu \mathrm{m})$ as indicated. The percentage of apoptotic cells was determined at $48 \mathrm{~h}$ as above (mean of $n=3$ independent experiments in quadruplicate \pm S.E.M.). (h) H345 cells were treated as above and the percentage of apoptotic cells was assessed by surface expression of annexin $\mathrm{V}$ using flow cytometry (mean of $n=3$ experiments \pm S.E.M.)

prevent apoptosis in SCLC cells through activation of $\beta 1$ integrins and tyrosine kinase signaling pathways.

\section{Laminin and $\mathrm{Na}_{3} \mathrm{VO}_{4}$ stimulate PI3-kinase activity, PKB phosphorylation and activity, and increase glycogen synthase kinase-3 (GSK-3) $\beta$ phosphorylation}

Integrin-dependent cell adhesion triggers an increase in tyrosine phosphorylation and PI3-kinase activation. ${ }^{19}$
PI3-kinase has also been shown to mediate matrix-induced survival in normal epithelial cells. ${ }^{24}$ Therefore, we examined if ECM proteins activated PI3-kinase signaling pathways in SCLC cells. Adhesion of H345 cells to ECM proteins laminin and fibronectin stimulated a marked increase in PI3-kinase activation (average $3.1 \times$ and $2.9 \times$ increases in PI3-kinase activity, respectively, $n=3$ independent experiments in quadruplicate) (Figure 2a). Furthermore, the $\beta 1$ integrinstimulating antibody TS2/16 $(10 \mu \mathrm{g} / \mathrm{ml})$ and $\mathrm{Na}_{3} \mathrm{VO}_{4}(200 \mu \mathrm{M})$ increased PI3-kinase activity by a similar amount to ECM (average $2.5 \times$ and $2.8 \times$ increases, respectively, $n=3$ 
a

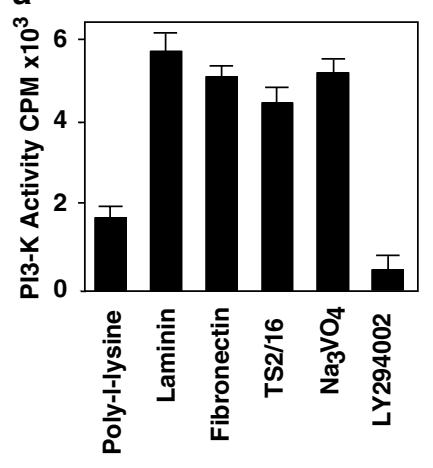

d

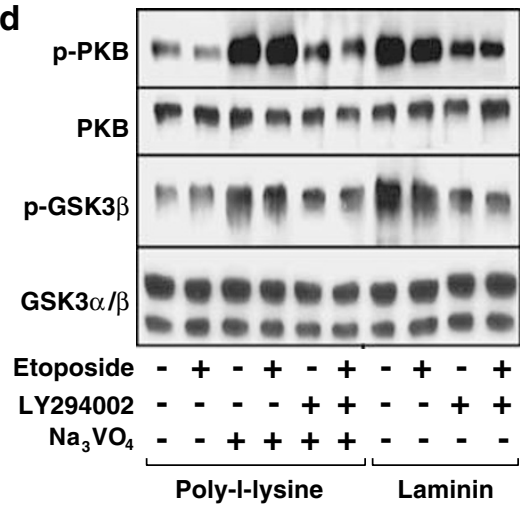

b

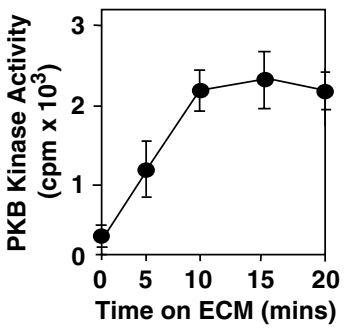

C

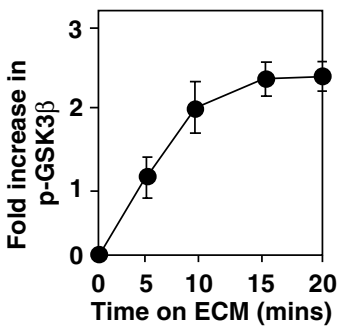

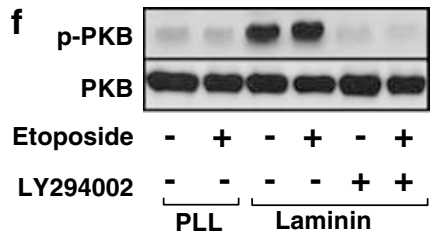

Figure 2 ECM activates PI3-kinase signaling in SCLC cells. (a) H345 cells were adhered to 6-well plates precoated with poly-L-lysine $(10 \mu \mathrm{g} / \mathrm{ml})$, laminin (10 $\mu \mathrm{g} / \mathrm{ml})$, fibronectin $(20 \mu \mathrm{g} / \mathrm{ml})$ or TS2/16 $(10 \mu \mathrm{g} / \mathrm{ml})$. In addition, cells on poly-L-lysine were treated with $\mathrm{Na}_{3} \mathrm{VO}_{4}(200 \mu \mathrm{m})$ or LY294002 $(30 \mu \mathrm{M})$ as indicated. PI3-kinase activity was assayed after $10 \mathrm{~min}$ as described in Materials and Methods. (b) Quiesced H345 cells were adhered to laminin for the times indicated and PKB activity was determined as described in Materials and Methods. (c) Quiesced H345 cells were adhered to laminin for the times indicated and expression of phosphorylated GSK3 $\beta$ was determined by Western blot analysis. Relative protein expression was quantified using Image $\mathrm{J}$ software (mean of $n=3$ experiments \pm S.E.M.). (d) H345 cells were adhered to six-well plates precoated with poly-L-lysine $(10 \mu \mathrm{g} / \mathrm{ml})$ or laminin $(10 \mu \mathrm{g} / \mathrm{ml})$ and treated with $(+)$ or without $(-)$ etoposide $\left(25 \mu \mathrm{g} / \mathrm{ml}^{2}\right)$, Na $3 \mathrm{VO}_{4}(200 \mu \mathrm{M})$ or LY294002 $(30 \mu \mathrm{M})$ as indicated. Cells were lysed after $10 \mathrm{~min}$, and expression of phosphorylated protein kinase B (p-PKB), total PKB, phosphorylated glycogen synthase kinase $3 \beta$ (p-GSK $3 \beta$ ) and glycogen synthase kinase $3 \alpha / \beta$ (GSK $3 \alpha / \beta)$ was determined by Western blot analysis. Representative blots from $n=3$ experiments. (e) Relative expression of phospho-PKB from cells treated as above. Graph represents the mean fold increase in phospho-PKB expression normalized to untreated controls $(n=3$ experiments \pm S.E.M.). (f) H345 cells were quiesced, plated onto laminin or poly-L-lysine, and treated as indicated. Cells were lysed after $48 \mathrm{~h}$ and phospho-PKB ( $p$-PKB) and total PKB expression was determined by Western blot. Representative blot from $n=3$ experiments

independent experiments in quadruplicate). As predicted, LY294002 reduced basal levels of PI3-kinase activity. PKB and GSK-3 $\beta$, which are downstream effectors of PI3-kinase and regulate cell survival, may also participate in overriding chemotherapy- and radiation-induced apoptosis in SCLC cells. Adhesion of H345 SCLC cells to laminin caused a timedependent increase in PKB activity, noted first at $5 \mathrm{~min}$ with maximum activity at $10 \mathrm{~min}$ (Figure $2 \mathrm{~b}$ ). An increase in GSK3 $\beta$ phosphorylation was also noted at $5 \mathrm{~min}$, rising to a plateau at $15 \mathrm{~min}$ (Figure 2c). Similar results were seen with fibronectin and TS2/16 (results not shown). Furthermore, $\mathrm{Na}_{3} \mathrm{VO}_{4}$ $(200 \mu \mathrm{M})$ stimulated PKB and GSK3 $\beta$ phosphorylation in H345 cells adhered to poly-L-lysine (Figure $2 d$ and e). The ECM-mediated increase in phosphorylation of PKB and GSK3 $\beta$ was sensitive to PI3-kinase inhibition with LY294002
$(10 \mu \mathrm{M})$ and was not affected by etoposide treatment $(25 \mu \mathrm{g} /$ $\mathrm{ml}$ ) (Figure $2 \mathrm{~d}$ and $\mathrm{e}$ ). In addition, the inhibition of PKB phosphorylation by LY294002 was prolonged in H345 cells, being observed up to $48 \mathrm{~h}$ after treatment (Figure 2f). Similar effects were seen in $\mathrm{H} 69$ SCLC cells (data not shown).

\section{ECM protection against etoposide-induced apoptosis is dependent on tyrosine kinase and phosphotidyl inositol 3-kinase activation}

To specifically investigate the role of PI3-kinase signaling in ECM-mediated chemoprotection, we initially used a pharmacological inhibitor of PI3-kinase activity, LY294002. Analysis of annexin V staining at $48 \mathrm{~h}$ in H345 SCLC cells adhered to 
poly-L-lysine revealed that inhibition of PI3-kinase with LY294002 produced a small increase in the degree of apoptosis both with and without etoposide (Figure 3a). Furthermore, the protection of H345 SCLC cells against etoposide-induced apoptosis mediated by ECM was completely reversed by the addition of LY294002 (Figure 3a). In addition, chemoprotection resulting from specific $\beta 1$ integrin stimulation with $\mathrm{TS} 2 / 16$ or stimulation of the tyrosine kinase pathway with $\mathrm{Na}_{3} \mathrm{VO}_{4}$ was abrogated by LY294002. Similar results were seen in $\mathrm{H} 69$ and $\mathrm{H} 510$ SCLC cells. As expected, z-valine-alanine-aspartate (z-VAD), which inhibits caspase activity, prevented apoptosis induced by etoposide (Figure 3a).

PI3-kinase activates downstream PKB, which phosphorylates proapoptotic factors such as caspase-9 and Bad, preventing cell death. ${ }^{21-23}$ Thus, we investigated whether ECM could alter Bad phosphorylation and etoposide-induced caspase-9 activation in a PI3-kinase-dependent manner. We found that adhesion of H345 SCLC cells to ECM stimulated phosphorylation of Bad and prevented cleavage of caspase- 9 induced by etoposide after $24 \mathrm{~h}$ (Figure $3 \mathrm{~b}$ ). These effects were prevented by treatment with LY294002. Activation of caspase-9 initiates cleavage of the 'effector' caspase-3, which ultimately results in apoptosis. We found that etoposide could induce caspase-3 cleavage in H345 cells adhered to polyL-lysine, but not in cells adhered to laminin. However, treatment with LY294002 prevented laminin from blocking caspase-3 cleavage without affecting caspase-3 activation in cells adhered to poly-L-lysine (Figure $3 \mathrm{~b}$ ). In parallel experiments, caspase-3 activity was measured (Figure 3c). Etoposide induced an increase in caspase-3 activity in H345 SCLC cells, which, as expected, was blocked by z-VAD. Adhesion to laminin and stimulation of the tyrosine kinase pathway with $\mathrm{Na}_{3} \mathrm{VO}_{4}$ overcame etoposide-induced caspase-3 activation, preventing cells undergoing apoptosis. Furthermore, the ECM- and $\mathrm{Na}_{3} \mathrm{VO}_{4}$-mediated inhibition of etoposide-induced caspase- 3 activation was prevented by the tyrosine kinase inhibitor tyrophostin-25 and the PI3-kinase inhibitor LY294002 (Figure 3c). These results indicate that PI3-kinase signaling, through phosphorylation of Bad and modulation of caspase activity, is critical for ECM-mediated resistance to etoposideinduced apoptosis in SCLC cells.

\section{ECM proteins override etoposide- and radiation- induced G2/M cell cycle arrest via PI3-kinase modulation of cell cycle regulators}

DNA damage is central to the cellular response to chemotherapy and radiation and results in cell cycle arrest predominantly at the G1/S and G2/M checkpoints. ${ }^{8,14}$ Subsequent, activation of checkpoint signaling cascades can result in apoptotic cell death preventing accumulation of genetic damage. Modulation of cell cycle checkpoints may therefore play an important role in sensitivity to radiation and chemotherapy. We investigated whether ECM proteins could override cell cycle arrest induced in SCLC cells by etoposide and radiation. H345 SCLC cells were adhered to poly-L-lysine or laminin, treated with etoposide $(25 \mu \mathrm{g} / \mathrm{ml})$ or ionizing radiation (2Gray (Gy)), and nuclear DNA content was assessed after $24 \mathrm{~h}$ by a

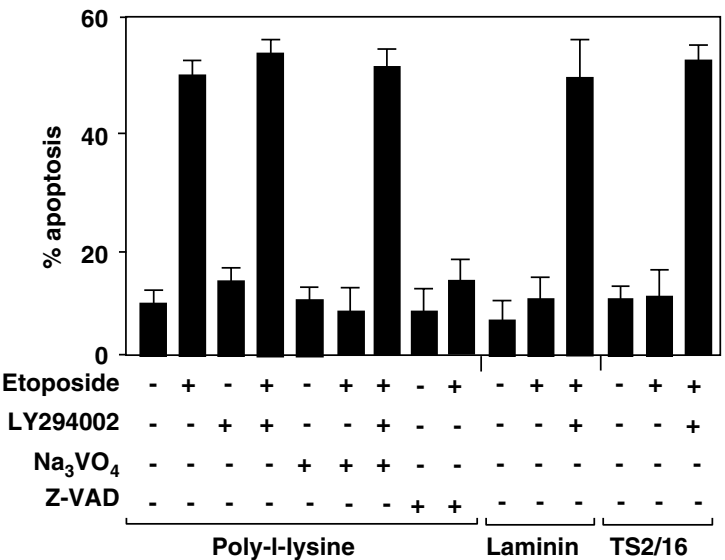

b

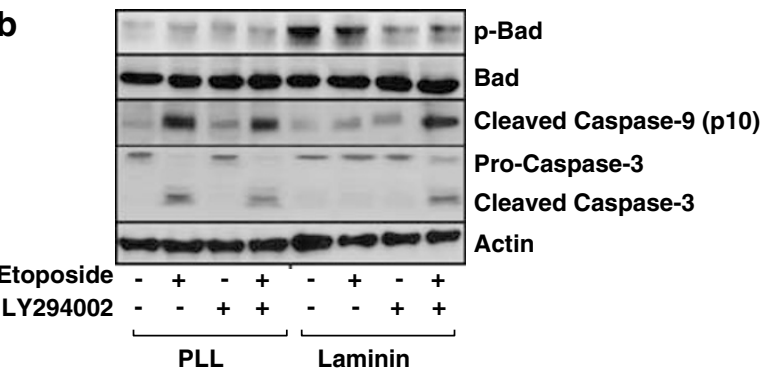

C

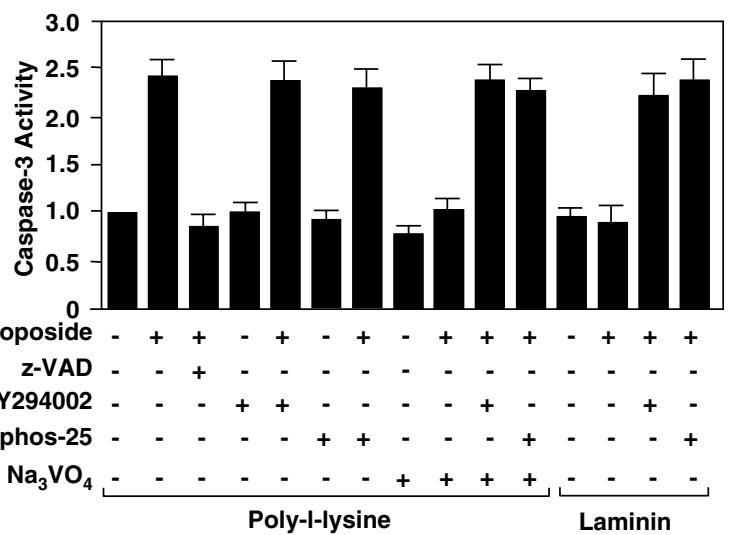

Figure 3 ECM-mediated protection from caspase-3 activation and apoptosis requires PI3-kinase signaling. (a) Quiesced $\mathrm{H} 345$ cells were seeded into 96-well plates precoated with poly-L-lysine $(10 \mu \mathrm{g} / \mathrm{ml})$, laminin $(10 \mu \mathrm{g} / \mathrm{ml})$ or TS2 $/ 16$ $(10 \mu \mathrm{g} / \mathrm{ml})$, allowed to adhere for $1 \mathrm{~h}$ and then treated with $(+)$ or without $(-)$ etoposide $(25 \mu \mathrm{g} / \mathrm{ml}), \mathrm{Na}_{3} \mathrm{VO}_{4}(200 \mu \mathrm{M})$ or LY294002 $(30 \mu \mathrm{M})$ as indicated. The percentage of apoptotic cells was assessed at $48 \mathrm{~h}$ by flow-cytometric analysis of surface annexin $\mathrm{V}$ staining (mean of $n=3$ independent experiments \pm S.E.M.). (b) Quiesced $\mathrm{H} 345$ cells were seeded into six-well plates precoated with poly-Llysine $(10 \mu \mathrm{g} / \mathrm{ml})$ or laminin $(10 \mu \mathrm{g} / \mathrm{ml})$ and treated with $(+)$ or without $(-)$ etoposide $(25 \mu \mathrm{g} / \mathrm{ml})$ or LY294002 $(30 \mu \mathrm{M})$ as indicated. After $24 \mathrm{~h}$ the cells were lysed and the expression of phospho-Bad ( $p$-Bad), Bad, cleaved caspase-9 ( 10 ) and caspase- 3 was determined by Western blot. Representative blots from $n=3$ experiments are shown. Actin is shown as a loading control. (c) Quiesced H345 cells were seeded into six-well plates precoated with poly-L-lysine $(10 \mu \mathrm{g} / \mathrm{ml})$ or laminin $(10 \mu \mathrm{g} / \mathrm{ml})$ and treated with $(+)$ or without $(-)$ etoposide $(25 \mu \mathrm{g} / \mathrm{ml}), \mathrm{z}-$ VAD $(100 \mu \mathrm{M})$, LY294002 (30 $\mu \mathrm{M})$, tyrphostin-25 (tyrpho-25) $(25 \mu \mathrm{M})$ or $\mathrm{Na}_{3} \mathrm{VO}_{4}$ $(200 \mu \mathrm{M})$ as indicated. Caspase-3 activity was measured after $48 \mathrm{~h}$ as described in Materials and Methods, and normalized to untreated cells on poly-L-lysine (mean of $n=3$ experiments \pm S.E.M.) 
flow-cytometric analysis of propidium iodide staining. H345 SCLC cells showed similar cell cycle profiles whether grown in suspension or adhered to poly-L-lysine or laminin (Figure 4a). At $24 \mathrm{~h}$ after treatment with etoposide $(25 \mu \mathrm{g} / \mathrm{ml})$ or ionizing radiation (2 Gy), H345 SCLC cells adhered to poly-L-lysine showed a significant increase in the percentage of cells in the $S$ and $\mathrm{G} 2 / \mathrm{M}$ phases of the cell cycle, with a reciprocal reduction in the percentage of cells in G1 (Figure $4 a$ and Table 1). In contrast, H345 cells adhered to laminin and treated with etoposide or ionizing radiation showed only a small increase in the percentage of cells in S and G2/M phase, with a minimal reciprocal reduction in the percentage of cells in G1. Similar results were observed with fibronectin (data not shown).

To investigate whether ECM proteins protect against cell cycle arrest via activation of $\beta 1$ integrin/PI3-kinase signalling, we treated $\mathrm{H} 345$ SCLC cells adhered to poly-L-lysine or laminin with etoposide for $24 \mathrm{~h}$ in the presence of the $\beta 1$ integrin function-blocking antibody 4B4, the $\beta 1$ integrin-

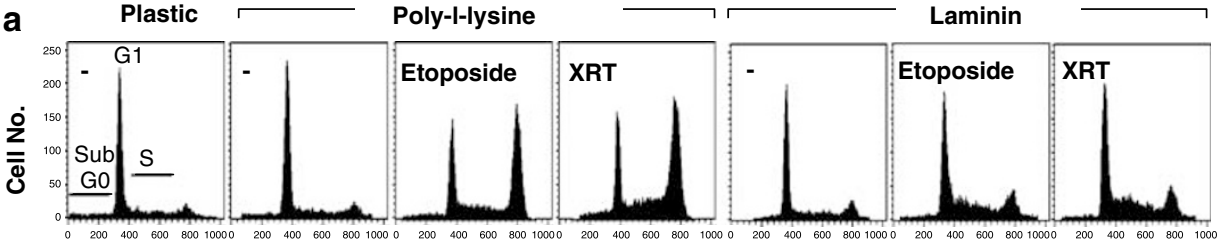

PI area

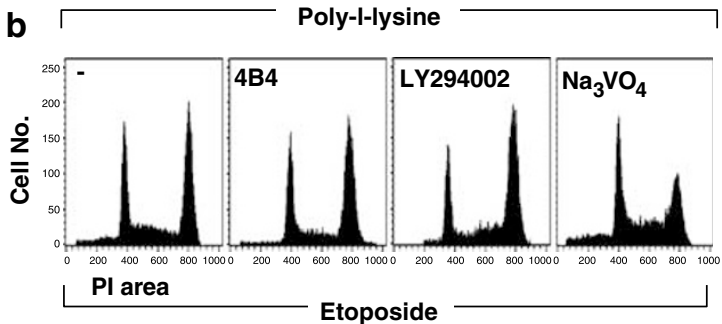

C
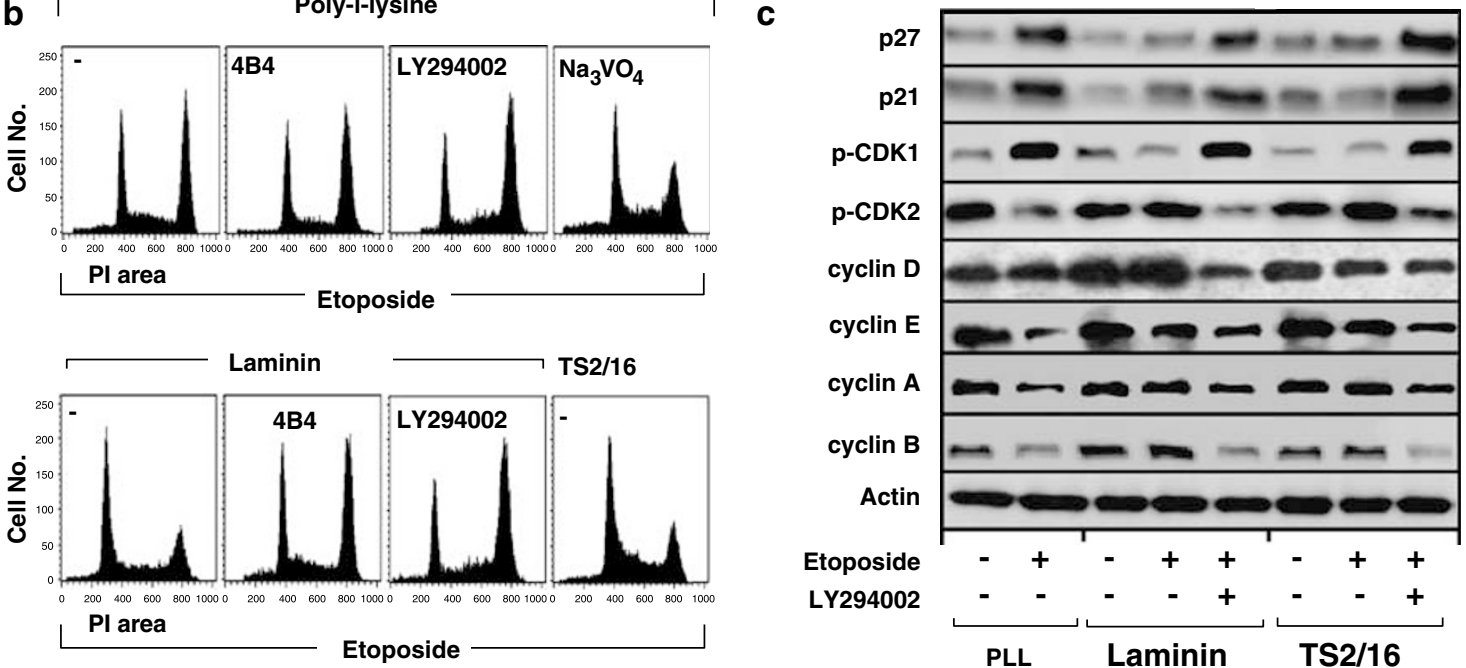

Figure 4 ECM overrides etoposide- and radiation-induced cell cycle arrest via $\beta 1$ integrin-mediated PI3-kinase activation. (a) H345 cells were quiesced overnight, washed twice and seeded into a six-well tissue culture plate, uncoated (plastic) or precoated with poly-L-lysine (10 $\mu \mathrm{g} / \mathrm{ml})$ or laminin (10 $\mu \mathrm{g} / \mathrm{ml})$. Cells were treated as indicated: no further treatment (-), etoposide $(25 \mu \mathrm{g} / \mathrm{ml})$ or ionizing radiation (2 Gy) (XRT). Progression through the cell cycle was assessed $24 \mathrm{~h}$ later by flow-cytometric analysis of DNA content using CELL Quest software. Representative histograms are shown from $n=5$ independent experiments. (b) Quiesced H345 SCLC cells were seeded into six-well tissue culture plates precoated with poly-L-lysine $(10 \mu \mathrm{g} / \mathrm{ml})$ or laminin $(10 \mu \mathrm{g} / \mathrm{ml})$ and treated with etoposide (25 $\mu \mathrm{g} / \mathrm{ml})$. In addition, cells were treated as indicated: blockade of $\beta 1$ integrin function with 4B4 (10 $\mu \mathrm{g} / \mathrm{ml})$, stimulation of $\beta 1$ integrins with TS2/16 (10 $\mu \mathrm{g} / \mathrm{ml})$, inhibition of PI3-kinase with LY294002 $(30 \mu \mathrm{M})$ or activation of tyrosine kinase with $\mathrm{Na}_{3} \mathrm{VO}_{4}(200 \mu \mathrm{M})$. Progression through the cell cycle was assessed $24 \mathrm{~h}$ later by flow-cytometric analysis of DNA content using CELL Quest software. Representative histograms are shown from $n=5$ independent experiments. (c) H345 SCLC cells were seeded into six-well plates precoated with poly-L-lysine $(10 \mu \mathrm{g} / \mathrm{ml})(\mathrm{PLL})$, laminin $(10 \mu \mathrm{g} / \mathrm{ml})$ or TS2/16 $(10 \mu \mathrm{g} / \mathrm{ml})$. Cells were treated with $(+)$ or without $(-)$ etoposide $(25 \mu \mathrm{g} / \mathrm{ml})$, LY294002 $(30 \mu \mathrm{M})$ or $\mathrm{Na}_{3} \mathrm{VO}_{4}(200 \mu \mathrm{M})$ as indicated. Cells were lysed after $24 \mathrm{~h}$ and the expressions of p21 ${ }^{\text {Cip1/WAF1 }}$, p27 ${ }^{\mathrm{Kip} 1}$, phosphorylated CDK1 (p-CDK1), phosphorylated CDK2 (p-CDK2) and cyclins D, E, A and B were determined by Western blot analysis. Representative blot from $n=3$ experiments. Actin is shown as a loading control

Table 1 ECM protects SCLC cells from etoposide- and radiation-induced cell cycle arrest

\begin{tabular}{|c|c|c|c|c|c|c|c|}
\hline \multirow[b]{2}{*}{ Cell cycle phase } & \multirow{2}{*}{$\begin{array}{c}\text { Plastic } \\
-\end{array}$} & \multicolumn{3}{|c|}{ Poly-L-Iysine } & \multicolumn{3}{|c|}{ Laminin } \\
\hline & & - & Etoposide & XRT & - & Etoposide & XRT \\
\hline $\begin{array}{l}\text { Sub-G0 } \\
\text { G1 } \\
\text { S } \\
\text { G2/M }\end{array}$ & $\begin{array}{r}5.6 \pm 1.6 \\
64.8 \pm 2.5 \\
17.3 \pm 2.0 \\
8.8 \pm 1.0\end{array}$ & $\begin{array}{r}6.1 \pm 1.3 \\
65.3 \pm 2.8 \\
18.2 \pm 1.7 \\
9.1 \pm 0.6\end{array}$ & $\begin{array}{r}4.9 \pm 2.4 \\
23.2 \pm 2.3 \\
25.4 \pm 1.6 \\
46.2 \pm 1.5\end{array}$ & $\begin{array}{r}5.4 \pm 1.4 \\
22.1 \pm 1.8 \\
24.5 \pm 2.1 \\
47.8 \pm 2.1\end{array}$ & $\begin{array}{r}6.3 \pm 1.7 \\
67.1 \pm 3.1 \\
16.7 \pm 2.3 \\
8.4 \pm 2.1\end{array}$ & $\begin{array}{r}5.1 \pm 1.1 \\
53.2 \pm 1.9 \\
22.2 \pm 1.7 \\
16.8 \pm 2.0\end{array}$ & $\begin{array}{r}3.5 \pm 1.7 \\
60.1 \pm 2.6 \\
20.1 \pm 1.8 \\
16.1 \pm 1.9\end{array}$ \\
\hline
\end{tabular}

H345 cells were quiesced overnight, washed twice and seeded into a six-well tissue culture plate, uncoated (plastic) or precoated with poly-L-lysine or laminin. Cells were treated as indicated: no further treatment $(-)$, etoposide or ionizing radiation (XRT). Progression through the cell cycle was assessed $24 \mathrm{~h}$ later by flow cytometric analysis of DNA content using CELL Quest software. Mean percentage of total cells in each phase of the cell cycle is shown from $n=5$ experiments \pm S.E.M. 
Table 2 ECM overrides etoposide- and radiation-induced cell cycle arrest via $\beta 1$ integrin-mediated PI3-kinase activation

\begin{tabular}{lrrrr}
\hline & \multicolumn{4}{c}{ Poly-L-lysine } \\
\cline { 2 - 5 } Cell cycle phase & \multicolumn{1}{c}{-} & \multicolumn{1}{c}{ 4B4 } & \multicolumn{1}{c}{ LY294002 } & $\mathrm{Na}_{3} \mathrm{VO}_{4}$ \\
\hline Sub-G0 & $3.6 \pm 1.7$ & $4.9 \pm 1.1$ & $4.3 \pm 0.9$ & $4.5 \pm 0.7$ \\
G1 & $24.2 \pm 3.9$ & $23.2 \pm 2.2$ & $22.1 \pm 2.5$ & $39.8 \pm 1.8$ \\
S & $22.6 \pm 2.1$ & $20.8 \pm 2.8$ & $19.3 \pm 1.3$ & $24.5 \pm 2.1$ \\
G2/M & $48.2 \pm 3.1$ & $46.9 \pm 2.8$ & $52.5 \pm 3.0$ & $28.6 \pm 2.0$ \\
& & Laminin & & TS2/16 \\
& & & & \\
Cell cycle phase & - & 4B4 & LY294002 & - \\
\hline Sub-G0 & $4.2 \pm 2.1$ & $4.3 \pm 1.1$ & $3.2 \pm 0.9$ & $4.1 \pm 2.1$ \\
G1 & $52.3 \pm 3.1$ & $22.8 \pm 2.0$ & $20.9 \pm 1.7$ & $44.2 \pm 1.8$ \\
S & $20.2 \pm 1.9$ & $19.7 \pm 3.0$ & $16.1 \pm 2.4$ & $28.7 \pm 2.2$ \\
G2/M & $18.4 \pm 2.5$ & $51.2 \pm 2.2$ & $58.8 \pm 3.1$ & $21.7 \pm 2.6$
\end{tabular}

H345 SCLC cells were seeded into six-well tissue culture plates precoated with poly-L-lysine, laminin or TS2/16 and treated with etoposide. In addition, cells were treated as indicated: blockade of $\beta 1$ integrins with 4B4, inhibition of PI3kinase with LY294002 or activation of tyrosine kinase with sodium orthovanadate $\left(\mathrm{Na}_{3} \mathrm{VO}_{4}\right)$. Progression through the cell cycle was assessed $24 \mathrm{~h}$ later by flow cytometric analysis of DNA content using CELL Quest software. Mean percentage total cells in each phase of the cell cycle is shown from $n=5$ independent experiments \pm S.E.M.

stimulating antibody TS2/16, $\mathrm{Na}_{3} \mathrm{VO}_{4}$ or LY294002, and assessed progression through the cell cycle (Figure $4 \mathrm{~b}$ and Table 2). Blockade of $\beta 1$ integrins with $4 \mathrm{~B} 4$ completely abrogated laminin-mediated protection from G2/M cell cycle arrest induced by etoposide in H345 SCLC cells without affecting cell cycle arrest in cells adhered to poly-L-lysine. Furthermore, laminin-mediated protection from etoposideinduced G2/M cell cycle arrest was blocked by inhibition of PI3-kinase with LY294002. In addition, stimulation of $\beta 1$ integrins on $\mathrm{H} 345$ SCLC cells with TS2/16 or activation of tyrosine kinase with $\mathrm{Na}_{3} \mathrm{VO}_{4}$ reduced etoposide-induced G2/ $M$ cell cycle arrest, simulating the effects of ECM. These results indicate that protection of SCLC cells from etoposideinduced cell cycle arrest by ECM proteins is mediated via $\beta 1$ integrin activation of PI3-kinase signaling.

DNA damage can activate p21 Cip1/WAF1 and p27 Kip1 and inhibit Cdc25s (activator of CDK1) to cause G1/S and G2/M arrest. ${ }^{8}$ PI3-kinase has been shown to induce expression of D-type cyclins and to increase stability of cyclin-D1 through PKB-dependent phosphorylation of GSK3 $\beta .{ }^{21}$ Therefore, we investigated whether ECM proteins could modulate cell cycle regulators through PI3-kinase and thus prevent G2/M cell cycle arrest. After $24 \mathrm{~h}$ of etoposide treatment, H345 SCLC cells showed an increase in expression of the CDK inhibitors p21 $1^{\mathrm{Cip} 1 / \mathrm{WAF} 1}$ and $\mathrm{p} 27^{\mathrm{Kip} 1}$ and phosphorylated CDK1 (inactive form) with decreased expression of phosphorylated CDK2 (active form) and cyclins E, A and B (Figure 4d). Adhesion of $\mathrm{H} 345$ SCLC cells to laminin increased cyclin D expression and blocked the etoposide-induced changes in p21 Cip1/WAF1, p27 ${ }^{\text {Kip1 }}$, phosphorylated CDK1 and 2, and cyclins E, A and B. Similar results were seen with fibronectin (data not shown). Furthermore, the effects of ECM were simulated by TS2/16 antibodies, but with less pronounced effects due to the bivalent nature of antibody binding, which will produce less integrin clustering and three-dimensional changes than laminin. The ability of laminin or TS2/16 to overcome etoposide-induced changes in cell cycle regulators was blocked by the PI3-kinase inhibitor LY294002. These results indicate that ECM proteins via $\beta 1$ integrins can override etoposide-induced G2/M cell arrest by modulating expression of cyclins, CDKs and CDK inhibitors in a PI3-kinasedependent manner.

\section{Expression of a dominant-negative PKB mutant prevents, and a constitutively active PKB mutant mimics, ECM-mediated protection from apoptosis and cell cycle arrest}

Although LY294002 is accepted as a specific inhibitor of PI3kinase/PKB signaling at the doses used, it can inhibit other pathways that may affect cell survival. Therefore, we sought to genetically interfere with PI3-kinase signaling in SCLC cells to confirm the effects of LY294002 on ECM-mediated chemoprotection. We have shown that binding of SCLC cells to ECM leads to activation of PI3-kinase, which activates PKB. Thus, to specifically examine downstream PKB signaling, we interfered with the activity of PKB through the expression of both constitutively active (PKB CA) and dominant-negative (PKB DN) PKB mutants. We found that transient expression of PKB DN in H345 SCLC cells markedly inhibited phosphorylation of downstream GSK3 $\beta$, whereas expression of PKB CA increased phospho-GSK3 $\beta$ levels, in accordance with the expected activity of these mutants on PKB signaling (Figure 5a). Importantly, expression of PKB CA protected $\mathrm{H} 345$ cells adhered to poly-L-lysine from etoposideinduced apoptosis (Figure 5b). Expression of PKB DN produced a small increase in apoptosis both with and without etoposide treatment in cells adhered to poly-L-lysine. However, PKB DN markedly increased etoposide-induced apoptosis in cells adhered to laminin (Figure $5 b$ ). Similar results were obtained with $\mathrm{H} 69$ cells (data not shown).

To confirm the results obtained with LY294002 on ECM-mediated protection from G2/M arrest, we transiently expressed PKB DN and PKB CA in H345 cells adhered to poly-L-lysine or laminin and analyzed progression through the cell cycle. In cells adhered to poly-L-lysine, transient expression of PKB CA reversed etoposide-induced G2/M arrest (Figure 5c and Table 3). Transient expression of PKB DN in cells adhered to poly-L-lysine caused a modest increase in the G2/M population with and without etoposide treatment. Importantly, expression of PKB DN in cells adhered to laminin significantly reversed protection from etoposide-induced G2/ $M$ arrest and caused a small, but significant, increase in G2/M arrest without etoposide treatment (Figure $5 \mathrm{c}$ and Table 3 ). Taken together, the results observed with LY294002 and the PKB mutants suggest a central role for PI3-kinase/PKB signaling in ECM-mediated chemoprotection in SCLC cells.

\section{Adhesion to ECM proteins does not modulate ongoing etoposide- and radiotherapy-induced DNA damage or repair}

In order to confirm that the antiapoptotic and cell cycle effects of ECM were not due to a reduction in etoposide activity or altered repair of etoposide- and radiation-induced DNA 
a

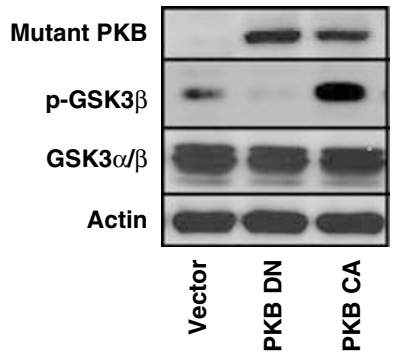

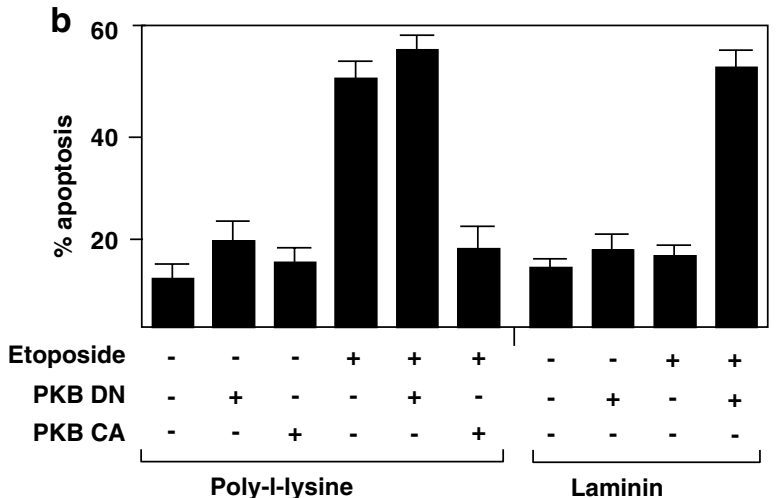

Poly-I-lysine

Laminin

\section{c}
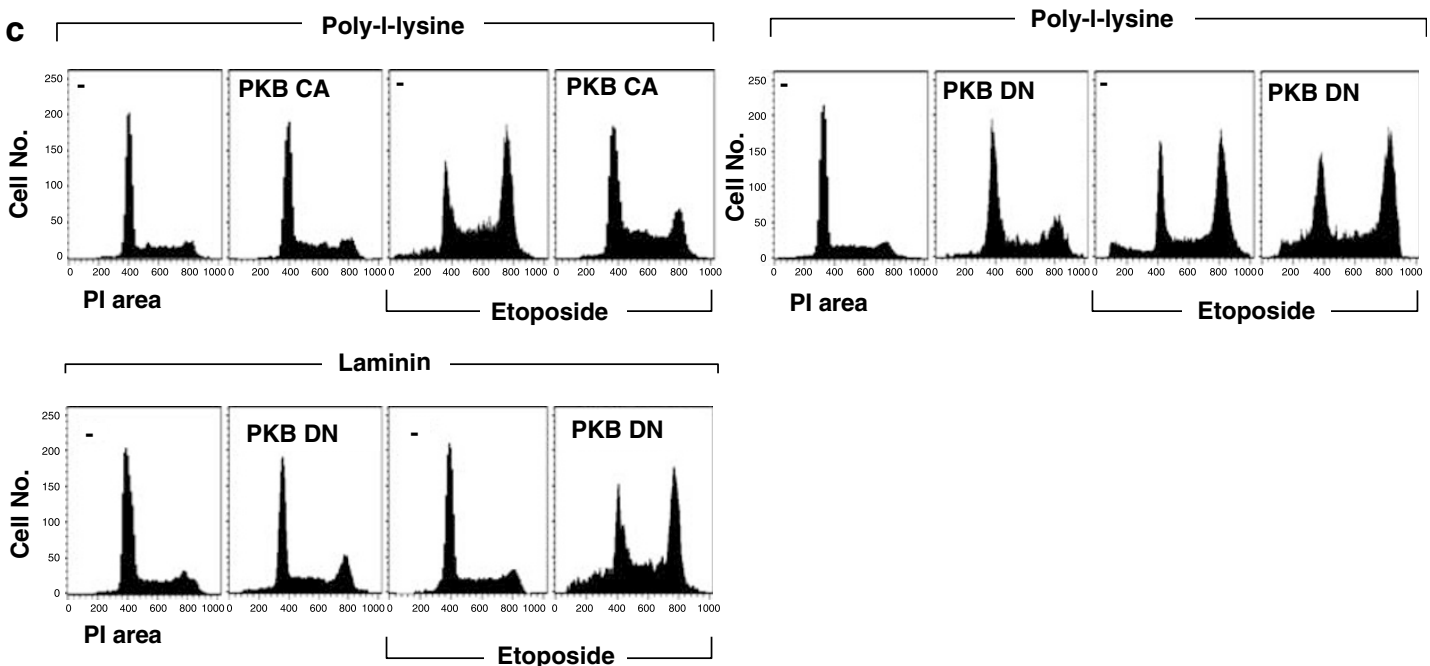

Figure 5 Expression of a dominant-negative PKB mutant prevents, and a constitutively active PKB mutant mimics, ECM-mediated protection from apoptosis and cell cycle arrest. (a) H345 SCLC cells were transfected with equal amounts of empty vector (pUSEamp), dominant-negative PKB (PKB DN) or constitutively active PKB (PKB CA). After $48 \mathrm{~h}$, cells were lysed and expression of the myc-tagged PKB mutants, GSK3 $\alpha / \beta$ and phospho-GSK3 $\alpha$ (p-GSK3 $\alpha$ ) was determined by Western blot. (b) H345 cells were transfected with equal amounts of PKB DN $(+)$ PKB CA $(+)$ or empty pUSEamp $(-)$ as indicated. After $24 \mathrm{~h}$ cells were quiesced, resuspended in SITA, plated onto poly-L-lysine or laminin and treated with etoposide as indicated. After $48 \mathrm{~h}$ the percentage of apoptotic cells was determined by flow-cytometric analysis of annexin V. (c) H345 cells were transfected with equal amounts of dominant-negative PKB (PKB DN) $(+)$, constitutively active PKB (PKB CA) $(+)$ or pUSEamp $(-)$. After $24 \mathrm{~h}$ the cells were quiesced, seeded into six-well plates precoated with poly-L-lysine or laminin and treated with etoposide as indicated. Progression through the cell cycle was assessed $24 \mathrm{~h}$ later by flow-cytometric analysis of DNA content using CELL Quest software. Representative histograms are shown from $n=5$ independent experiments

damage, we assessed Topo II activity and DNA double-strand break formation and repair. Topo II resolves sister chromatid entanglement by binding to DNA, cleaving both strands and passing a second duplex through the first before reannealing the cleavage site. ${ }^{25}$ Etoposide blocks the reannealing action of Topo II after the enzyme has created a double-strand break leading to activation of DNA damage signaling pathways and ultimately apoptosis. ${ }^{25}$ We measured Topo II activity by the ATP-dependent de-catenation of high-molecular-weight DNA. While etoposide was able to inhibit Topo II activity, adhesion to the ECM protein laminin did not affect etoposide inhibition of Topo II activity or Topo II expression. The PI3kinase inhibitor LY294002 had no effect on either Topo II expression or activity (Figure 6a).

To determine the amount of DNA damage induced by etoposide and radiation, $\mathrm{H} 345$ cells were seeded onto plastic precoated with poly-L-lysine or laminin and then treated as specified. The cells were washed, allowed to recover, and the amount of DNA double-strand breaks in cell nuclei was determined by immunofluorescence staining of phosphorylated $\mathrm{H} 2 \mathrm{AX}(\gamma \mathrm{H} 2 \mathrm{AX})$. The foci of $\gamma \mathrm{H} 2 \mathrm{AX}$ represent actual DNA double-strand breaks and correlate closely with cell death in response to DNA damage (Figure $6 b$ and $c$ ). ${ }^{26}$ DNA doublestrand breaks were also confirmed by Western blotting for $\gamma \mathrm{H} 2 \mathrm{Ax}$ and DNA-dependent protein kinase catalytic subunit (DNA-PKcs) (Figure 6d). A very marked and equal increase in $\gamma \mathrm{H} 2 \mathrm{Ax}$ foci was seen $2 \mathrm{~h}$ after etoposide (30 min after radiotherapy - data not shown). Over the following 24-h period, there was a decrease in the number of double-strand breaks as DNA damage was repaired (Figure $6 b-d)$. Crucially there was no difference in the amount of DNA damage or rate of repair in response to etoposide or radiation between cells plated on laminin or nonspecifically adhered to plastic by polyL-lysine. Interestingly, while nearly all of the DNA damage was repaired, there were still a significant number of $\gamma \mathrm{H} 2 \mathrm{Ax}$ foci present at $24 \mathrm{~h}$, suggesting persistence of DNA damage. 
Table 3 Expression of dominant-negative PKB prevents, and constitutively active PKB mimics, ECM-mediated protection from $\mathrm{G} 2 / \mathrm{M}$ cell cycle arrest

\begin{tabular}{|c|c|c|c|c|}
\hline \multirow[b]{2}{*}{ Cell cycle phase } & \multicolumn{2}{|c|}{ Poly-L-lysine } & \multicolumn{2}{|c|}{ Etoposide treatment } \\
\hline & - & PKB CA & - & PKB CA \\
\hline \multirow[t]{2}{*}{$\begin{array}{l}\text { Sub-G0 } \\
\text { G1 } \\
\text { S } \\
\text { G2/M }\end{array}$} & $\begin{array}{r}4.3 \pm 0.7 \\
63.2 \pm 2.9 \\
15.6 \pm 1.8 \\
12.2 \pm 1.1\end{array}$ & $\begin{array}{r}4.1 \pm 0.8 \\
60.1 \pm 3.3 \\
17.3 \pm 1.6 \\
14.2 \pm 1.1\end{array}$ & $\begin{array}{r}8.3 \pm 1.3 \\
19.6 \pm 2.1 \\
27.3 \pm 1.4 \\
53.5 \pm 3.0\end{array}$ & $\begin{array}{r}3.6 \pm 0.9 \\
49.8 \pm 1.8 \\
21.5 \pm 3.1 \\
22.6 \pm 2.3\end{array}$ \\
\hline & \multicolumn{2}{|c|}{ Poly-L-lysine } & \multicolumn{2}{|c|}{ Etoposide treatment } \\
\hline Cell cycle phase & - & PKB DN & - & PKB DN \\
\hline \multirow[t]{2}{*}{$\begin{array}{l}\text { Sub-G0 } \\
\text { G1 } \\
\text { S } \\
\text { G2/M }\end{array}$} & $\begin{array}{r}3.2 \pm 0.7 \\
61.3 \pm 3.9 \\
17.3 \pm 2.1 \\
14.2 \pm 2.1\end{array}$ & $\begin{array}{r}4.1 \pm 0.8 \\
51.6 \pm 3.3 \\
20.4 \pm 1.9 \\
23.2 \pm 3.1\end{array}$ & $\begin{array}{r}7.5 \pm 2.3 \\
24.6 \pm 1.9 \\
26.8 \pm 2.4 \\
47.5 \pm 3.1\end{array}$ & $\begin{array}{r}8.9 \pm 1.7 \\
27.6 \pm 1.9 \\
26.8 \pm 2.7 \\
43.6 \pm 3.8\end{array}$ \\
\hline & \multicolumn{2}{|c|}{ Laminin } & \multicolumn{2}{|c|}{ Etoposide treatment } \\
\hline Cell cycle phase & - & PKB DN & - & PKB DN \\
\hline $\begin{array}{l}\text { Sub-G0 } \\
\text { G1 } \\
\text { S } \\
\text { G2/M }\end{array}$ & $\begin{array}{r}4.0 \pm 1.8 \\
64.5 \pm 3.0 \\
16.2 \pm 1.7 \\
11.6 \pm 2.1\end{array}$ & $\begin{array}{r}4.2 \pm 1.9 \\
47.6 \pm 1.5 \\
24.5 \pm 2.9 \\
21.2 \pm 2.0\end{array}$ & $\begin{array}{r}3.1 \pm 0.7 \\
55.3 \pm 2.2 \\
20.6 \pm 1.1 \\
15.2 \pm 1.0\end{array}$ & $\begin{array}{r}8.1 \pm 1.1 \\
20.8 \pm 2.2 \\
27.7 \pm 1.7 \\
49.2 \pm 2.1\end{array}$ \\
\hline
\end{tabular}

H345 cells were transfected with equal amounts of dominant-negative PKB (PKB DN), constitutively active PKB (PKB CA) or empty vector $(-)$. After $24 \mathrm{~h}$, the cells were quiesced, seeded into six-well plates precoated with poly-L-lysine or laminin and treated with etoposide as indicated. Progression through the cell cycle was assessed $24 \mathrm{~h}$ later by flow cytometric analysis of DNA content using CELL Quest software. Mean percentage of total cells in each phase of the cell cycle is shown from $n=5$ independent experiments \pm S.E.M.

\section{Discussion}

Our results show for the first time that ECM proteins activate $\beta 1$ integrins to protect SCLC cells against the proapoptotic effects of the DNA damaging agents, etoposide and ionizing radiation through tyrosine kinase-mediated PI3-kinase activation. Etoposide, which inhibits the re-annealing activity of Topo II causing DNA damage, upregulates CDK inhibitors p21 ${ }^{\text {Cip } 1 / W A F 1}$ and p27 $7^{\text {Kip } 1}$, increases CDK 1 phosphorylation and downregulates cyclins $\mathrm{D}, \mathrm{E}, \mathrm{A}$ and $\mathrm{B}$ and CDK 2 phosphorylation, causing G2/M cell cycle arrest. In SCLC cells $\beta 1$ integrin-mediated PI3-kinase activation via phosphorylation of PKB and GSK-3 $\beta$ leads to maintenance of cyclins $D$, $\mathrm{E}, \mathrm{A}$ and $\mathrm{B}$, increases expression of phosphorylated CDK2 and downregulates CDK inhibitors, p21 $1^{\mathrm{Cip} 1 \mathrm{WAF} 1}$ and p2 $7^{\mathrm{Kip} 1}$ despite the presence of etoposide. This leads to continued progression through the cell cycle, overriding etoposideinduced G2/M arrest. Furthermore, adhesion of SCLC cells to $E C M$ via $\beta 1$ integrin/PI3-kinase signaling results in phosphorylation of Bad and reduced caspase-9 cleavage, in response to etoposide, preventing apoptosis. The interrelationship of ECM effects on G2/M progression and apoptosis is not clear, but it is likely that through PI3-kinase ECM overrides these processes in parallel, to effect cell survival and proliferation. Importantly, the effects of ECM occur despite etoposideinduced Topo II inhibition and extensive DNA damage. As a consequence, SCLC cells in the presence of ECM are resistant to chemotherapeutic agents and continue to cycle despite genetic abberations, possibly leading to the

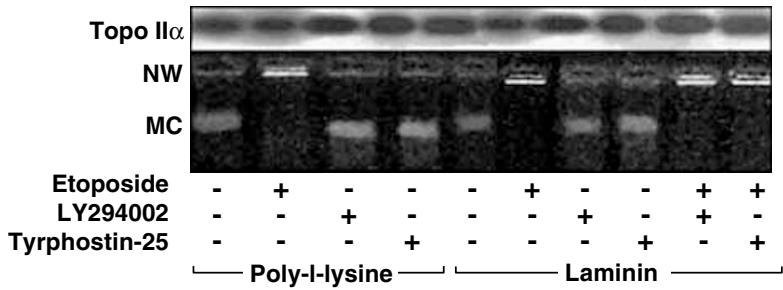

b Untreated
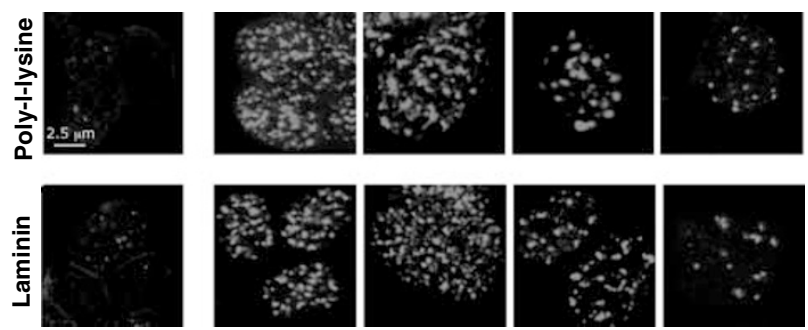

0

6

12

24

Time after etoposide wash out (Hours)

C

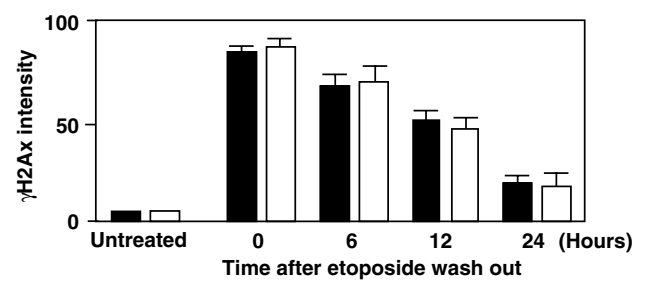

d

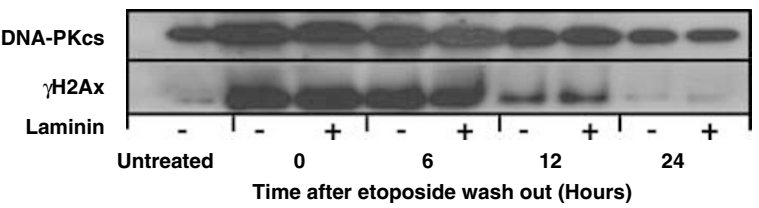

Figure 6 Adhesion to ECM does not affect etoposide-induced Topo II inhibition or DNA double-strand break formation and repair. (a) H345 cells were adhered to poly-L-lysine or laminin and treated with ( + ) or without (-) etoposide $(25 \mu \mathrm{g} / \mathrm{ml})$, LY294002 (30 mM) or tyrphostin-25 (25 mM) as indicated. Nuclear extracts were prepared and Topo II activity was determined by ATP-dependent decatenation of kinetoplast DNA (kDNA) as described in Materials and Methods. A representative UV gel is shown (from $n=3$ independent experiments): $M C$ - decatenated individual DNA mini-circles (active Topo II), NW - high-molecular-weight interlocking kDNA network (inactive Topo II)). In parallel samples, Topo II expression was determined by Western blot analysis. (b) Quiesced H345 SCLC cells were adhered for $1 \mathrm{~h}$ to eight-well coverslides precoated with poly-L-lysine $(10 \mu \mathrm{g} / \mathrm{ml})$ or laminin $(10 \mu \mathrm{g} / \mathrm{ml})$ and treated with etoposide $(25 \mu \mathrm{g} / \mathrm{ml})$ for $2 \mathrm{~h}$. Cells were washed twice and the medium was replaced with RPMl containing $10 \%$ FCS. Cells were fixed at 0-24 $\mathrm{h}$ after removal of etoposide as indicated, stained with anti- $\gamma \mathrm{H} 2 \mathrm{Ax}$ antibody and foci viewed by fluorescence microscopy. Representative images of $\gamma \mathrm{H} 2 \mathrm{Ax}$ foci from $n=4$ independent experiments. Untreated cells are shown for comparison. (c) H345 SCLC cells were seeded into eight-well coverslips precoated and treated with poly-L-lysine (closed bars) or laminin (open bars) and allowed to adhere for $1 \mathrm{~h}$. The cells were treated with etoposide $(25 \mu \mathrm{g} / \mathrm{ml})$ for $2 \mathrm{~h}$, washed and allowed to recover in RPMI with FCS. Cells were fixed at $0-24 \mathrm{~h}$ after removal of etoposide as indicated, stained with anti- $\gamma \mathrm{H} 2 \mathrm{Ax}$ antibody and foci viewed by fluorescence microscopy The intensity of $\gamma \mathrm{H} 2 \mathrm{Ax}$ staining in 10 high-power fields was quantified with Openlab image analysis software for each condition and normalized to untreated cells (mean relative $\gamma \mathrm{H} 2 \mathrm{Ax}$ foci of $n=4$ experiments). (d) $\mathrm{H} 345$ cells were adhered to poly-L-lysine $(-)$ or laminin $(+)$, treated with etoposide $(25 \mu \mathrm{g} / \mathrm{ml})$ and lysed at the times indicated. Expression of DNA-PKcs and $\gamma \mathrm{H} 2 \mathrm{Ax}$ was determined by Western blot analysis. Representative blot from $n=3$ independent experiments 
emergence of drug-resistant clones. As the DNA damage is random, genetic drug resistance can be achieved as a result of a wide variety of insults, explaining why no unifying mechanism for the emergence of MDR in SCLC has been defined.

The development of MDR is a major cause of treatment failure in cancer. ${ }^{2}$ Central to the cellular response to DNA damage is cell cycle arrest at regulated checkpoints with subsequent activation of cell death by apoptosis. ${ }^{8}$ MDR is a multi-factorial phenomenon, and therefore it may be more effective to target the processes which enhance survival and prevent apoptosis induced by initial drug treatment in cancer cells, preventing the emergence of acquired drug resistance. ${ }^{27}$ Resistance mechanisms in vitro differ from those in vivo, suggesting that the local cellular environment plays a significant role in selection for in vivo drug resistance. Our previous results in SCLC suggest that in vivo interactions between tumor cells and ECM proteins in the microenvironment are involved in the early stages of drug selection, providing a survival advantage to ECM adherent SCLC cells, and promote the acquisition of the classical forms of drug resistance.

Detachment of anchorage-dependent cells results in apoptotic cell death. ${ }^{28}$ This can be prevented by constitutive activation of integrin-dependent signaling pathways such as PI3-kinase and PKB. ${ }^{29}$ While anchorage-independent growth is a major step in cellular transformation leading to cancer and metastases, cancer cells may still use integrin survival signals. Our work and results from other groups show that a number of cancers, including SCLC, breast, prostate, colon cancer and hematological malignancies, all use ECM adhesion for survival to evade the cytotoxic effects of chemotherapy or radiotherapy. ${ }^{3,5-7}$ While this appears to be a general and important phenomenon, the actual intracellular mechanisms coupling integrin activation to protection from chemotherapy- and radiotherapy-induced apoptosis may be cancer cell type specific. The mechanisms described here for SCLC differ from those reported previously, particularly myeloma cells. This may reflect cell type specificity potentially relating to differing integrin behavior between hematological malignancies and solid tumors. Previous studies in hemapoeitic tumor cells have demonstrated that adhesion to fibronectin protected against chemotherapeutic agents through increased expression of $\mathrm{p} 27^{\mathrm{Kip} 1}$ and $\mathrm{G} 1$ cell cycle arrest. $^{30}$ Furthermore, integrin-mediated adhesion in hemapoeitic cancer cells reduced DNA double-strand breaks and apoptosis caused by chemotherapeutic agents such as mitoxantrone and etoposide. ${ }^{31}$ This primarily $\alpha 5 \beta 1$-mediated reduction in DNA damage correlated with decreased topoisomerase-II enzymatic activity. However, the $\alpha 5 \beta 1$ integrin is not found in SCLC cells and is reduced in other carcinomas. ${ }^{3,32}$ Furthermore, our results show that, in SCLC cells grown in suspension or adhered to ECM proteins such as laminin and fibronectin, the enzymatic activity of topoisomerase-II and the amount of etoposide- or radiation-induced DNA double-strand breaks remain unchanged. In addition, the rate of proliferation is also unaffected by adhesion to ECM proteins. These results demonstrate that decreased proliferation and changes in Topo II activity are not the mechanisms of integrin-mediated drug resistance in SCLC cells.
The PI3-kinase/PKB pathway contributes to the pathogenesis of cancer and confers resistance to apoptosis. ${ }^{19,33}$ Activated PI3-kinase phosphorylates inositol lipids, resulting in the activation of the serine/threonine kinase PKB that phosphorylates caspase- 9 and BAD, promoting cell survival. ${ }^{19}$ Activated PKB can also regulate cellular proliferation by interaction in the nucleus with cell cycle regulators governing G1/S and G2/M checkpoints. ${ }^{34}$ In this study, we have shown that inhibition of PI3-kinase prevents $\beta 1$ integrins from overriding etoposide-induced G2/M cell cycle arrest and apoptosis, indicating that PI3-kinase is crucial for ECMmediated chemoprotection in SCLC cells. Previous work has indicated that inhibition of growth factor stimulated PI3-kinase activity, promotes apoptosis and enhances sensitivity of SCLC cells to chemotherapy. ${ }^{18}$ Primarily, we found that pharmacological and genetic inhibition of PI3-kinase/PKB signaling dramatically reversed ECM-mediated chemoprotection. However, we did observe an increase in apoptosis measured by annexin $\mathrm{V}$ staining at $48 \mathrm{~h}$ with inhibiton of PI3kinase signaling both with and without etoposide. These results confirm previous data by Krystal et al. (2002), but the effects on apoptosis were less pronounced in our system, possibly due to differences in experimental design and cell types examined. This small effect on apoptosis is in keeping with previous data published on the use of LY294002. ${ }^{18,35}$

Integrins and growth factors in untransformed cells only regulate cell cycle progression at the G1/S checkpoint. ${ }^{11}$ Current evidence suggests a central role for PI3-kinase signaling pathway in regulating cell cycle progression. PI3kinase activation can be sufficient to induce $\mathrm{G} 1$ transit in fibroblasts. ${ }^{34}$ Thus, downstream targets of PI3-kinase/PKBdependent pathways that regulate normal cell cycle progression may also participate in overriding etoposide- and radiation-induced cell cycle checkpoints. PI3-kinase activity has been shown to induce expression of D-type cyclins and to increase cyclin D1 stability through PKB-dependent phosphorylation of GSK-3 $\beta .^{21} \mathrm{G} 1$ progression depends on the sustained expression of $D$ type cyclins. The cyclin D-CDK 4 and 6 complex sequesters the CDK inhibitors p21 Cip1/WAF1 and $\mathrm{p} 27^{\mathrm{Kip} 1}$, which allows cyclin E-CDK 2 to drive the cell cycle through late $\mathrm{G} 1$, allowing the derepression of cyclin $A$ at the onset of $S$ phase. ${ }^{16}$ Deletion of the $p 2{ }^{\text {Kip } 1}$ gene restores the growth phenotype of cyclin D1 null mice. ${ }^{36}$ Furthermore cells, which overexpress cyclin E, still depend on cyclin D1 accumulation to sequester the enhanced p21 ${ }^{\text {Cip1/WAF1 levels, }}$ suggesting that a major function of cyclin D1 in cell cycle control is the redistribution of CDK inhibitors. ${ }^{37}$ PI3-kinase effects on G1-phase progression may also be mediated through the downregulation of expression and function of p27 Kip1 38 Thus, adhesion to ECM via integrin-mediated activation of PI3-kinase may reduce levels of $\mathrm{p} 21^{\text {Cip1/WAF1 }}$ and $p 27^{\mathrm{Kip} 1}$, allowing cells to progress through the $\mathrm{G} 1 / \mathrm{S}$ phase of the cell cycle.

SCLC cells have previously been shown to have a defective G1/S checkpoint, which correlates with mutant inactive $p 53 .{ }^{39}$ We confirm the reports of others that etoposide and ionizing radiation lead to G2/M cell cycle arrest in SCLC cells. Furthermore, our data clearly demonstrate that the $\beta 1$ integrin/PI3-kinase pathway in SCLC cells regulates progression through the $\mathrm{G} 2 / \mathrm{M}$ checkpoint. The ability of $\beta 1$ integrins to 
overide etoposide-induced G2/M arrest in SCLC cells could result from increased DNA repair, thus removing signals for cell cycle arrest. Importantly, we found no difference in the degree of DNA damage induced by etoposide or XRT in cells adhered to either laminin or poly-L-lysine. Furthermore, when cells were allowed to recover, we observed identical rates of DNA repair. This suggests that ECM-mediated protection from G2/M arrest is not caused by alterations in the amount of DNA damage or the kinetics of DNA repair. The finding of identical DNA repair is interesting because laminin, by driving cells through the G2/M cell cycle checkpoint, might reduce the time scale for effective DNA repair, resulting in increased amounts of damaged DNA. However, previous data have demonstrated that DNA repair can occur at all stages of the cell cycle and cells have mechanisms for tolerating damaged DNA, allowing replication of the genome. ${ }^{40}$ Therefore, it is possible that, in cells driven through the G2 checkpoint by laminin, damaged DNA is tolerated, to be repaired during other phases of the cell cycle. This could result in similar apparent levels of DNA double-strand break repair between cells adhered to laminin and poly-L-lysine. Importantly, tolerating mechanisms are more likely to introduce point mutations, increasing the likelihood of long-term genetic damage.

Crucially, what we have demonstrated in this paper is that etoposide treatment of SCLC cells adhered to poly-L-lysine induces DNA double-strand breaks causing G2/M cell cycle arrest and ultimately apoptotic cell death via caspase activation. However, although etoposide induces identical DNA damage in cells adhered to ECM, $\beta 1$ integrin/PI3-kinase activation by ECM proteins prevents prolonged G2/M arrest by downregulating $\mathrm{p} 21^{\mathrm{Cip} 1 / \mathrm{WAF} 1}$ and $\mathrm{p} 27^{\mathrm{Kip} 1}$, reduces phosphorylation of CDK1, maintains expression of cyclin D, E, A and $B$ and phosphorylates CDK2. Thus, adhesion to ECM allows SCLC cells to survive following significant treatmentinduced DNA damage, increasing the likelihood of propagation of genetic mutations, providing an explanation for the acquisition of MDR following initial therapy.

$\beta 1$ integrin-mediated adhesion between tumor cells and the ECM in their environment confers a survival advantage to SCLC cells, protecting from apoptosis and allowing cells with damaged DNA to drive through the cell cycle. This may lead to the propagation of further transforming genetic mutations, which may ultimately cause acquired MDR in what were initially chemo-sensitive cells. Thus, the environmental context and specificity of cancer cells may have important consequences on the acquisition of MDR and therapies designed to disrupt specific interactions between cells, and their environment may be important targets in the circumvention of MDR. This has important implications for the role of dose intensification and adjuvant treatment by inhibiting $\beta 1$ integrin/PI3 kinase signaling to enhance the cytotoxic effects of chemotherapy. However, integrins play a key role particularly in the immune system and protection against infection; thus targeting $\beta 1$ integrins may have deleterious side effects. Our initial observations on cell-adhesion mediated drug resistance have been shown to be widely applicable in a number of cancers including breast, colon and hematological cancers. We believe the mechanisms outlined in this article will also have broad implications, particularly in cancers that are initially sensitive to cytotoxic treatment and then become resistant. A better understanding of the $\beta 1$ specific mechanisms mediating integrin protection against the proapoptotic effect of DNA damaging drugs may lead to the development of novel therapeutic strategies in the circumvention of MDR.

\section{Materials and Methods}

\section{Cell culture}

All experiments used $\mathrm{NCl}-\mathrm{H} 69, \mathrm{NCl}-\mathrm{H} 345$ and $\mathrm{NCl}-\mathrm{H} 510$ cell lines from ATCC (Rockville, MD, USA) which were grown in HEPES buffered RPMI 1640 medium (Invitrogen) supplemented with 10\% (v/v) heat-inactivated fetal calf serum (FCS) (Labtec), $5 \mu \mathrm{g} / \mathrm{ml}$ L-glutamine, $100 \mathrm{U} / \mathrm{ml}$ penicillin and $100 \mu \mathrm{g} / \mathrm{ml}$ streptomycin (Invitrogen Ltd, UK). For experiments, cells were cultured overnight in quiescent media (RPMl supplemented with $0.25 \%$ (w/v) BSA, $100 \mathrm{U} / \mathrm{ml}$ penicillin and $100 \mu \mathrm{g} / \mathrm{ml}$ streptomycin), and then resuspended in SITA media (RPMI supplemented with $30 \mathrm{nM}$ selenium, $5 \mu \mathrm{g} / \mathrm{ml}$ insulin, $10 \mu \mathrm{g} / \mathrm{ml}$ transferrin, $0.25 \%(\mathrm{w} / \mathrm{v}) \mathrm{BSA}, 100 \mathrm{U} / \mathrm{ml}$ penicillin and $100 \mu \mathrm{g} / \mathrm{ml}$ streptomycin). FCS contains fibronectin $(25 \mu \mathrm{g} /$ $\mathrm{ml}$ ), which will stimulate $\beta 1$ integrin/PI3-kinase signaling, and therefore it was necessary to remove FCS prior to and during experiments examining the effects of ECM on SCLC cells.

\section{Transfection of cell lines}

Plasmids encoding myc-tagged constitutively active PKB-pUSEamp myr$A k t 1 / P K B \alpha$ and myc-tagged dominant-negative PKB-pUSEamp Akt1/ $P K B \alpha(\mathrm{K} 179 \mathrm{M})$ were obtained from Upstate Biotechnology. pUSEamp was used as an empty vector control. Plasmid inserts were sequenced prior to use. For transfection $\mathrm{H} 345$ and $\mathrm{H} 69$ cells were washed twice, resuspended in antibiotic free culture RPMI $\left(0.5 \times 10^{6} \mathrm{cell} / \mathrm{s} / \mathrm{ml}\right)$ and transfected with $1 \mu \mathrm{g}$ of DNA $/ 10^{6}$ cells using Lipofectamine $2000(1: 5$ ratio) according to the manufacturer's instructions.

\section{Apoptosis}

SCLC cells were quiesced by overnight incubation at $37^{\circ} \mathrm{C}$ in quiescent medium. Cells were washed twice and seeded $\left(4 \times 10^{4}\right.$ cells in $200 \mu \mathrm{l}$ of SITA per well) into 96 -well plates which had been precoated by incubation at $37^{\circ} \mathrm{C}$ for $1 \mathrm{~h}$ with poly-L-lysine $(10 \mu \mathrm{g} / \mathrm{ml})($ Sigma), laminin $(10 \mu \mathrm{g} / \mathrm{ml})$ (Sigma), fibronectin (20 $\mu \mathrm{g} / \mathrm{ml})$ (Sigma) or TS2/16 $(10 \mu \mathrm{g} / \mathrm{ml})$ (BioLegend) as specified. Cells were allowed to settle for $1 \mathrm{~h}$ at $37^{\circ} \mathrm{C}$ and then treated with $\mathrm{Na}_{3} \mathrm{VO}_{4}(200 \mu \mathrm{M})$ (Sigma), LY294002 $(30 \mu \mathrm{M})$ (Calbiochem), tyrphostin-25 $(25 \mu \mathrm{M})$ (Calbiochem) or etoposide ( $25 \mu \mathrm{g} / \mathrm{ml})$ (Sigma) as specified. Cells were treated with ionizing radiation (1-4 Gy) as specified using a $6 \mathrm{MV}$ linear accelerator. In experiments using 4B4 to block $\beta 1$ integrin function, cells were incubated with 4B4 $(10 \mu \mathrm{g} / \mathrm{ml})$ (Beckman Coulter) at $37^{\circ} \mathrm{C}$ for $30 \mathrm{~min}$ prior to seeding onto ECM. Apoptosis was assessed $0-72 \mathrm{~h}$ later by the addition of $1 \mu$ l of ethidium bromide $(1 \mathrm{mg} / \mathrm{ml})$ (Sigma) and $1 \mu \mathrm{l}$ acridine orange $(1 \mathrm{mg} / \mathrm{ml})$ (Sigma) and the percentage of apoptotic cells was determined by fluorescent microscopy as described previously. ${ }^{5}$ Apoptosis was also determined using a cell death detection ELISA $^{\mathrm{TM}}$ kit (based on the quantitative detection of histone-associated DNA fragments in mono- and oligonucleosomes) according to the manufacturer's instructions (Roche Diagnostics) and by flow-cytometric analysis of Annexin $V$ staining according to the manufacturer's instructions (Annexin V-PE BD Bioscience). 


\section{PI3-kinase activity assay}

PI3-K activity was measured as described previously. ${ }^{29}$ Briefly, cells were spun onto six-well plates precoated with poly-L-lysine $(10 \mu \mathrm{g} / \mathrm{ml})$ (Sigma), laminin $(10 \mu \mathrm{g} / \mathrm{ml})$ (Sigma), fibronectin $(20 \mu \mathrm{g} / \mathrm{ml})$ (Sigma) or TS2 $/ 16$ $(10 \mu \mathrm{g} / \mathrm{ml})$ (BioLegend) as specified and lysed. PI3-kinase was immunoprecipitated from protein-equilibrated cell lysates using a $10 \mu \mathrm{g}$ 1:1 mixture of anti-phosphotyrosine antibodies PY20 and PY99 (Upstate Biotechnology, Lake Placid, USA) and assayed for activity using $\left[\gamma-{ }^{32}\right.$ P]ATP and a mixture of phosphatidyl inositol and phosphatidyl serine as substrate. 3-Phosphorylated lipids were resolved using thin-layer chromatography after Folch extraction. $\mathrm{PIP}_{3}$ was identified by autoradiography and quantified by liquid scintillation counting.

\section{PKB activity}

PKB activity was measured as described previously. ${ }^{29}$ In brief, cells were quiesced overnight, gently disaggregated and then treated as specified. Cells were lysed, PKB was immunoprecipitated with anti-PKB $\alpha$ conjugated to protein $\mathrm{G}$-sepharose beads $\left(4^{\circ} \mathrm{C}\right.$ for $90 \mathrm{~min}$ ) and assayed for activity using $\left[\gamma_{-}{ }^{32}\right.$ P]ATP and crosstide substrate (Upstate Biotechnology). Radioactive incorporation was quantified by liquid scintillation counting.

\section{Caspase-3 activity}

Quiesced SCLC cells were adhered to poly-L-lysine (10 $\mu \mathrm{g} / \mathrm{ml})$ (Sigma), laminin $(10 \mu \mathrm{g} / \mathrm{ml})$ (Sigma), fibronectin $(20 \mu \mathrm{g} / \mathrm{ml})$ (Sigma), or TS2 $/ 16$ $(10 \mu \mathrm{g} / \mathrm{ml})$ (BioLegend) as specified and treated with $\mathrm{Na}_{3} \mathrm{VO}_{4}(200 \mu \mathrm{M})$ (Sigma), LY294002 (30 $\mu \mathrm{M})$ (Calbiochem), tyrphostin-25 (25 $\mu \mathrm{M})$ (Calbiochem), etoposide $(25 \mu \mathrm{g} / \mathrm{ml})$ (Sigma) or Z-VAD $(100 \mu \mathrm{M})$ (Promega) as indicated. Cells were lysed at $48 \mathrm{~h}$ and caspase-3 activity was assessed using a caspase-3 cellular activity kit according to the manufacturer's instructions (Cat. no. 235419 Calbiochem). Specific caspase-3 activity (pmol/ $\mathrm{min} / \mathrm{mg}$ protein) in each experiment was normalized to untreated cells.

\section{Western blotting}

Cells were treated as specified, lysed in RIPA buffer and protein balanced by BCA protein assay (Pierce). Samples were resolved on 10, 12 or $14 \%$ acrylamide gels $(10 \mu \mathrm{g}$ protein/lane) and separated proteins were transferred onto nitrocellulose membranes. Blots were probed with the following antibodies overnight at $4{ }^{\circ} \mathrm{C}$ in either $5 \%$ milk or $3 \%$ BSA in TBS Tween: rabbit anti-actin (Sigma); rabbit anti-phospho-PKB (Sigma), mouse anti-GSK-3 $\alpha / \beta$ (Biosource International), rabbit anti-phosphoGSK-3 $\beta$ (pS9) (Biosource International); mouse anti-p21 Cip1/WAF1 (clone CP74) (Sigma); mouse anti-p27 ${ }^{\text {Kip1 }}$ (clone DCS-72) (Sigma); mouse anticyclin A (Oncogene Research Products) mouse anti-cyclin B (BD Transduction Labs, USA); mouse anti-cyclin D1 (clone AM29) (Zymed); mouse anti-cyclin E (clone HE12) (Upstate); rabbit anti-phospho-CDK2 (Thr160), rabbit anti-phospho-CDK1 (Tyr15) (both Cell Signaling Technology, USA); mouse anti- $\gamma \mathrm{H} 2 \mathrm{Ax}$ (Upstate); mouse anti-DNA-PKcs (p350 clone 6) (BD Biosciences); rabbit anti-phospho-Bad (Ser136); rabbit anti-Bad (9292) (Cell Signaling Technology); rabbit anti-cleavage sitespecific caspase-9 antibody (CCSA 315/316) (Biosource); mouse anti-myc (9E10) (Abcam); and rabbit anti-caspase-3 (Asp179) (5A1). Speciesspecific horseradish peroxidase-conjugated antibodies (Dako) were used as secondary labels and bands were visualized using ECL (Amersham) according to manufacturer's instructions. Relative protein expression was quantified using Image $\mathrm{J}$ software.

\section{Cell cycle analysis}

Cells were quiesced overnight and seeded into six-well plates precoated with laminin, fibronectin or TS2/16 and treated as specified. Cells were fixed 0-24 $\mathrm{h}$ later in $70 \%$ ice-cold ethanol (for at least $2 \mathrm{~h}$ ), stained with propidium iodide and subjected to flow-cytometric analysis (pulse processing) with a FACS Calibur (BD Biosciences) flow cytometer. Cell cycle parameters from 10000 events were analyzed using CELLQuest software.

\section{Topo II activity}

Topo II activity was measured as described previously. ${ }^{3}$ Briefly, nuclei were extracted from SCLC cells treated as specified and lysed. The supernatant was used in a Topo II assay, which measures Topo II activity by the ATPdependent de-catenation of high-molecular-weight kinetoplast DNA (kDNA). Each sample was incubated for $30 \mathrm{~min}$ at $37^{\circ} \mathrm{C}$ in reaction buffer $(50 \mathrm{mM}$ Tris- $\mathrm{HCl}$ (pH 7.5), $10 \mathrm{mM} \mathrm{MgCl}_{2}, 100 \mathrm{mM} \mathrm{KCl}, 0.5 \mathrm{mM}$ EDTA, $30 \mu \mathrm{g} / \mathrm{ml}$ BSA, $1 \mathrm{mM}$ ATP, $0.5 \mathrm{mM}$ dithiothreitol and $100 \mu \mathrm{g} / \mathrm{ml} \mathrm{kDNA}$ (TopoGEN)). The reaction products were separated by $1 \%$ agarose gel electrophoresis, stained with ethidium bromide and photographed under UV light.

\section{Visualization of DNA double-strand breaks}

Cells were quiesced overnight and seeded into eight-well coverslides (Nalge NUNC) at a density of $2.5 \times 10^{5} \mathrm{cells} / \mathrm{cm}^{2}$ precoated with laminin or poly-L-lysine. Cells were allowed to adhere for $1 \mathrm{~h}$ at $37^{\circ} \mathrm{C}$ and then treated with etoposide $(25 \mu \mathrm{g} / \mathrm{ml})$ for $2 \mathrm{~h}$. Cells were then washed and allowed to recover in RPMI with FCS. Cells were fixed at $0-24 \mathrm{~h}$ after etoposide treatment with $3 \%$ paraformaldehyde for $5 \mathrm{~min}$, washed twice with PBS, permeabilized with $0.1 \%$ Triton and blocked with $0.2 \%$ fish skin gelatin. Cells were incubated with $1: 500$ dilution of anti- $\gamma \mathrm{H} 2 \mathrm{Ax}$ (Upstate) for $2 \mathrm{~h}$ at room temperature and washed with PBS. Secondary antibody labeled with ALEXAflour $488(1: 500)$ was applied for $1 \mathrm{~h}$ at room temperature. The slides were viewed using a Zeiss Axioskop 2 microscope. Image analysis was performed using Openlab software from Improvision.

\section{Statistical analysis}

Data were analyzed by one-way analysis of variance and the appropriate post-test analyses were applied. $P$-values $<0.05$ were considered to be significant.

\section{Acknowledgements}

This work was in part supported by the Wellcome Trust (UK) (Senior Research Leave Fellowship for TS), the Medical Research Council (Clinical Research Training Fellowships for PH and TE), the Melville Trust for the Care and Cure of Cancer and the British Lung Foundation. We would also like to acknowledge the kind support of the Edinburgh Cancer Centre and thank Professor Allan Price for technical advice.

\section{References}

1. Parkin DM, Bray F, Ferlay J and Pisani P (2005) Global cancer statistics, 2002. CA Cancer J. Clin. 55: 74-108

2. Elliott $T$ and Sethi $T$ (2002) Integrins and extracellular matrix: a novel mechanism of multi-drug resistance. Expert Rev. Anticancer Ther. 2: 449-459

3. Sethi T, Rintoul RC, Moore SM, MacKinnon AC, Salter D, Choo C, Chilvers ER, Dransfield I, Donnelly SC, Strieter R and Haslett C (1999) Extracellular matrix proteins protect small cell lung cancer cells against apoptosis: a mechanism for small cell lung cancer growth and drug resistance in vivo. Nat. Med. 5: 662-668 
4. Ridley AJ, Schwartz MA, Burridge K, Firtel RA, Ginsberg MH, Borisy G, Parsons JT and Horwitz AR (2003) Cell migration: integrating signals from front to back. Science 302: 1704-1709

5. Aoudjit $F$ and Vuori $K$ (2001) Integrin signaling inhibits paclitaxel-induced apoptosis in breast cancer cells. Oncogene 20: 4995-5004

6. Uhm JH, Dooley NP, Kyritsis AP, Rao JS and Gladson CL (1999) Vitronectin, a glioma-derived extracellular matrix protein, protects tumor cells from apoptotic death. Clin. Cancer Res. 5: 1587-1594

7. Kouniavsky G, Khaikin M, Zvibel I, Zippel D, Brill S, Halpern Z and Papa M (2002) Stromal extracellular matrix reduces chemotherapy-induced apoptosis in colon cancer cell lines. Clin. Exp. Metastasis 19: 55-60

8. Kastan MB and Bartek J (2004) Cell cycle checkpoints and cancer. Nature 432 316-323

9. Gregorc V, Darwish S, Ludovini V, Pistola L, De Angelis V, Mihaylova Z, Bellezza G, Sidoni A, Cavaliere A, Bucciarelli E, Massaro G and Tonato (2003) Relevance of $\mathrm{p} 53, \mathrm{bcl}-2$ and $\mathrm{Rb}$ expression on resistance to cisplatin-based chemotherapy in advanced non-small cell lung cancer. Lung Cancer 39: 41-48

10. Hui R, Finney GL, Carroll JS, Lee CS, Musgrove EA and Sutherland RL (2002) Constitutive overexpression of cyclin D1 but not cyclin $E$ confers acute resistance to antiestrogens in T-47D breast cancer cells. Cancer Res. 62: 6916-6923

11. Danen EH and Yamada KM (2001) Fibronectin, integrins, and growth control. Cell Physiol. 189: 1-13

12. Guadagno TM, Ohtsubo M, Roberts JM and Assoian RK (1993) A link between cyclin A expression and adhesion-dependent cell cycle progression. Science 262: 1572-1575

13. Fang F, Orend G, Watanabe N, Hunter T and Ruoslahti E (1996) Dependence of cyclin E-CDK2 kinase activity on cell anchorage. Science 271: 499-502

14. Massague J (2004) G1 cell-cycle control and cancer. Nature 432: 298-306

15. Boonstra J (2003) Progression through the G1-phase of the on-going cell cycle. J. Cell Biochem. 90: 244-252

16. Woo RA and Poon RY (2003) Cyclin-dependent kinases and S phase control in mammalian cells. Cell Cycle 2: 316-324

17. Zhu X, Ohtsubo M, Bohmer RM, Roberts JM and Assoian RK (1996) Adhesiondependent cell cycle progression linked to the expression of cyclin D1, activation of cyclin E-cdk2, and phosphorylation of the retinoblastoma protein. J. Cell Biol. 133: 391-403

18. Krystal GW, Sulanke G and Litz J (2002) Inhibition of phosphatidylinositol 3kinase-Akt signaling blocks growth, promotes apoptosis, and enhances sensitivity of small cell lung cancer cells to chemotherapy. Mol. Cancer Ther. 1 913-922

19. Downward J (2004) PI 3-kinase, Akt and cell survival. Semin. Cell Dev. Biol. 15: 177-182

20. Xia H, Nho RS, Kahm J, Kleidon J and Henke CA (2004) Focal adhesion kinase is upstream of phosphatidylinositol 3-kinase/Akt in regulating fibroblast survival in response to contraction of type I collagen matrices via a beta 1 integrin viability signaling pathway. J. Biol. Chem. 279: 33024-33034

21. Diehl JA, Cheng M, Roussel MF and Sherr CJ (1998) Glycogen synthase kinase-3beta regulates cyclin D1 proteolysis and subcellular localization. Genes Dev. 12: 3499-3511

22. Troussard AA, Tan C, Yoganathan TN and Dedhar S (1999) Cell-extracellular matrix interactions stimulate the AP-1 transcription factor in an integrin-linked kinase- and glycogen synthase kinase 3-dependent manner. Mol. Cell. Biol. 19: 7420-7427

23. Buss H, Dorrie A, Schmitz ML, Frank R, Livingstone M, Resch K and Kracht M (2004) Phosphorylation of serine 468 by GSK-3beta negatively regulates basal p65 NF-kappaB activity. Biol. Chem. 279: 49571-49574
24. Khwaja A, Rodriguez-Viciana P, Wennstrom S, Warne PH and Downward (1997) Matrix adhesion and Ras transformation both activate a phosphoinositide $3-\mathrm{OH}$ kinase and protein kinase B/Akt cellular survival pathway. EMBO J. 16: 2783-2793

25. Kaufmann SH (1989) Induction of endonucleolytic DNA cleavage in human acute myelogenous leukemia cells by etoposide, camptothecin, and other cytotoxic anticancer drugs: a cautionary note. Cancer Res. 49: 5870-5878

26. Olive PL (2004) Detection of DNA damage in individual cells by analysis of histone H2AX phosphorylation. Methods Cell Biol. 75: 355-373

27. Hannun YA (1997) Apoptosis and the dilemma of cancer chemotherapy. Blood 89: $1845-1853$

28. Ruoslahti E and Reed JC (1994) Anchorage dependence, integrins, and apoptosis. Cell 77: 477-478

29. Moore SM, Rintoul RC, Walker TR, Chilvers ER, Haslett C and Sethi T (1998) The presence of a constitutively active phosphoinositide 3-kinase in small cell lung cancer cells mediates anchorage-independent proliferation via a protein kinase B and p70s6k-dependent pathway. Cancer Res. 58: 5239-5247

30. Hazlehurst LA, Damiano JS, Buyuksal I, Pledger WJ and Dalton WS (2000) Adhesion to fibronectin via beta1 integrins regulates p27kip1 levels and contributes to cell adhesion mediated drug resistance (CAM-DR). Oncogene 19: 4319-4327

31. Hazlehurst LA, Valkov N, Wisner L, Storey JA, Boulware D, Sullivan DM and Dalton WS (2001) Reduction in drug-induced DNA double-strand breaks associated with beta1 integrin-mediated adhesion correlates with drug resistance in U937 cells. Blood 98: 1897-1903

32. Su JM, Gui L, Zhou YP and Zha XL (2002) Expression of focal adhesion kinase and alpha5 and beta1 integrins in carcinomas and its clinical significance. World J. Gastroenterol. 8: 613-618

33. Kang S, Bader AG and Vogt PK (2005) Phosphatidylinositol 3-kinase mutations identified in human cancer are oncogenic. Proc. Natl. Acad. Sci. USA 102: 802-807

34. Phillips-Mason PJ, Raben DM and Baldassare JJ (2000) Phosphatidylinositol 3-kinase activity regulates alpha-thrombin-stimulated $\mathrm{G} 1$ progression by its effect on cyclin D1 expression and cyclin-dependent kinase 4 activity. J. Biol. Chem. 275: 18046-18053

35. Tsurutani J, West KA, Sayyah J, Gills JJ and Dennis PA (2005) Inhibition of the phosphatidylinositol 3-kinase/Akt/mammalian target of rapamycin pathway but not the MEK/ERK pathway attenuates laminin-mediated small cell lung cancer cellular survival and resistance to imatinib mesylate or chemotherapy. Cancer Res. 65: 8423-8432

36. Tong W and Pollard JW (2001) Genetic evidence for the interactions of cyclin D1 and p27 (Kip1) in mice. Mol. Cell. Biol. 21: 1319-1328

37. Resnitzky D (1997) Ectopic expression of cyclin D1 but not cyclin E induces anchorage-independent cell cycle progression. Mol. Cell. Biol. 17: 5640-5647

38. Cappellini A, Tabellini G, Zweyer M, Bortul R, Tazzari PL, Billi AM, Fala F, Cocco L and Martelli AM (2003) The phosphoinositide 3-kinase/Akt pathway regulates cell cycle progression of HL60 human leukemia cells through cytoplasmic relocalization of the cyclin-dependent kinase inhibitor p27(Kip1) and control of cyclin D1 expression. Leukemia 17: 2157-2167

39. Smith PJ, Wiltshire M, Chin SF, Rabbitts P and Soues S (1999) Cell cycle checkpoint evasion and protracted cell cycle arrest in X-irradiated small-cell lung carcinoma cells. Int. J. Radiat. Biol. 75: 1137-1147

40. Potter AJ and Rabinovitch PS (2005) The cell cycle phases of DNA damage and repair initiated by topoisomerase II-targeting chemotherapeutic drugs. Mutat. Res. 572: 27-44 